\title{
GAZDASÁG ÉS ETNICITÁS
}

DOI: $10.17355 /$ rkkpt.v27i1.244

\section{CSATA ZSOMBOR $*$}

\section{Etnikai párhuzamosságok az erdélyi gazdaságban $^{1}$}

\section{Bevezetö}

$\mathrm{E}$ rdélyben az oktatással, a kultúrával vagy a médiával szemben a gazdaság intézményesülése elsősorban nem etnikai alapon történik, a gazdaságot általában nem egy etnikailag integrált társadalmi mezőnek tekintik. ${ }^{2}$ Románia a rendszerváltás után a piaci kapitalizmus útján indult el, ahol alapértelmezés szerint a gazdasági folyamatokat - hatósági reguláció és felügyelet mellett - a piac irányítja, a gazdasági döntéseket elsősorban utilitarista, hatékonyságelvü, profitszemléletü szempontok határozzák meg. A közgazdaságtan fóárama szerint az egyén társadalmi attribútumai a gazdaságban másodlagosak, a termelési folyamatban elsősorban a hozzáértését és a teljesítményét értékelik.

A gazdaságszociológiai elemzésekben viszont a gazdaság a modern kapitalizmusban sem független a társadalmi feltételektől, és sajátosan az etnikai viszonyoktól sem, ${ }^{3}$ a gazdasági döntésekben,

\footnotetext{
* A szerző az MTA TK Kisebbségkutató Intézetének tudományos munkatársa, egyetemi docens a kolozsvári Babeș-Bolyai Tudományegyetem Szociológia és Szociális Munkás Karán. E-mail: csata.zsombor@tk.mta.hu

1 A tanulmány megjelenését a Bolyai Kutatói Ösztöndíj támogatta (pályázat száma: BO 00604/17). A szerző köszönettel tartozik Kuczi Tibornak az elemzés általánosabb szemléletmódjával kapcsolatos tanácsaiért, Bethlendi Andrásnak, Csite Andrásnak, Hadas Miklósnak, Juhász Pálnak, Kerekes Kingának, Kiss Dénesnek, Pásztor Gyöngyinek és Péter Lászlónak, valamint a két anonim lektornak a további értékes észrevételeiért és javaslataiért.

${ }^{2}$ Kiss Tamás - Székely István Gergő - Toró Tibor - Bárdi Nándor - Horváth István (eds.): Unequal Accommodation of Minority Rights: Hungarians in Transylvania. Cham: Springer, 2018.

${ }^{3}$ Granovetter, Mark: Economic action and social structure: The problem of embeddedness. American Journal of Sociology, 1985. 91(3). 481-510.; Portes,
}

REGIO 27. évf. (2019) 1. szám 37-80. 
interakciókban, folyamatokban lépten-nyomon felbukkan az etnikai szempont. Hasonló álláspontot képvisel az új intézményi közgazdaságtan, amely az etnicitást a szociális koordináció egyik dimenziójának tekinti, ${ }^{4}$ aminek a jelentősége egy olyan gazdasági környezetben növekszik meg, ahol: 1. különböznek az egyes etnikai csoportok fogyasztói és kulturális preferenciái; 2. eltérőek az egyes etnikumok társadalmi pozíciói, nagyok közöttük a társadalmi egyenlőtlenségek; 3. az együttmüködés kikényszerítéséért felelős intézmények hatékonysága alacsony, ezekkel összefüggésben pedig 4. magas fokú az általános bizalmatlanság.

Ilyen feltételek mellett hatékonyabb lehet a gazdasági cselekvők viselkedésének az összehangolása, ha azok etnikailag és nyelvileg homogén kapcsolatok mentén történnek. Az összehangolás javarészt az etnikai alapú „korlátozott szolidaritáson”, „kikényszeríthető bizalmon”, vagy valamiféle közös „értékintrojekción” alapszik ${ }^{5}$, melyet a társadalmi tőke egy formájának tekintenek. Ezek jelenléte és intézményesülése hozzájárulhat az együttmüködés során felmerülő bizonytalanság és ezáltal a tranzakciós költségek csökkenéséhez, ami komparatív előnyt jelenthet a piac etnikailag nem integrált szereplőivel szemben. ${ }^{6} \mathrm{Az}$ együttmüködést zökkenőmentesebbé teheti az is, hogy az ugyanahhoz az etnikumhoz tartozók kollektív

Alejandro - Sensenbrenner, Julia: Embeddedness and immigration: Notes on the social determinants of economic action. American Journal of Sociology, 1993. 98(6). 1320-1350.; Light, Ivan - Gold, Steven: Ethnic Economies. San Diego, CA: Academic Press. 2000.; Alesina, Alberto - Eliana La Ferrara: Ethnic diversity and economic performance. Journal of Economic Literature, 2005. Volume 43, issue 3. 762-800.; Eriksen, Thomas Hylland: Economies of ethnicity. In: Carrier, James G. (ed.) A Handbook of Economic Anthropology. Cheltenham, UK Northampton, MA: Edward Elgar, 2005. 353-369.

${ }^{4}$ Landa, Janet T.: Trust, ethnicity, and identity: beyond the new institutional economics of ethnic trading networks, contract law, and gift-exchange. University of Michigan Press, 1994,; Wickström, Bengt-Arne - Landa, Janet Tai: Interethnic relations, informal trading networks, and social integration: imitation, habits, and social evolution. Journal of Bioeconomics, 2018. 20(3). 263-286.

5 Portes, Alejandro: Social capital: Its origins and applications in modern sociology. Annual Review of Sociology, 1998. 24(1). 1-24.

${ }^{6}$ Granovetter, Mark: The Economic Sociology of Firms and Entrepreneurs. In: Portes, Alejandro (ed.): Economic Sociology of Immigration. Essays on Network, Ethnicity and Entrepreneurship. New York: Russell Sage Foundation, 1995. 128162.

REGIO 27. évf. (2019) 1. szám 37-80. 
reprezentációi, valóságértelmezése és preferenciái nagyobb eséllyel egyeznek meg, könnyebben alakulhat ki konszenzus különböző döntési szituációkban. Szintén hatékonyabb a koordináció, ha nincsenek félrehallások amiatt, hogy a felek eltérö nyelveket beszélnek, illetve egy homogén nyelvi környezetben kisebbek a kommunikációs költségek is.

Ha viszont a körülmények a fentiektöl különböznek, a kizárólag etnikai alapon szerveződő gazdasági együttmüködés általában nem gazdaságos, jelentős alternatív költségei vannak. Egy homogén és zárt kommunikációs rendszerben, „etnikai burokban” redundáns információk keringenek, a tagok könnyebben lemaradnak jó üzleti lehetőségekről. Etnikai alapú zárványok, „szegregátumok” alakulhatnak ki, amelyek leszakadhatnak a piac jobban teljesítő részétöl. A diverzitás hiánya a vállalaton belül sem mindig hasznos, különösen a humán erőforrást intenzíven igénylö ágazatokban: a homogén munkacsoportok általában kevésbé innovatívak ${ }^{7}$, probléma-megoldási és adaptációs képességük alacsonyabb ${ }^{8}$, a munkatársak kevesebbet tanulnak egymástól, együttesen kisebb a teljesítményük.

Az etnikai gazdasággal foglalkozó szakirodalom a közösségen belüli, sürübbre szőtt kapcsolatokat úgynevezett bonding típusú kötéseknek is nevezi ${ }^{9}$. Ezek a közös hagyományok, a szokásrend, kultúra vagy éppen a többség általi szorongatottság kollektív megélése mentén alakulnak ki, és egy nagyobb belső szolidaritást és bizalmat eredményezhetnek. A kisebbségi csoporton kívülre mutató, ún. bridging kötések pedig azért felelősek, hogy az etnikum szélesebb társadalmi integrációja megvalósuljon. Mark Granovetter ${ }^{10}$ szerint sem a túlzottan nagy, sem a túlzottan alacsony belső szolidaritás nem előnyös a kisebbségi aktorok gazdasági helyzete, fejlődése szempontjából. Ahhoz, hogy sikeresek legyenek, meg kell találniuk a

\footnotetext{
${ }^{7}$ Page, Scott E.: The Difference: How the Power of Diversity Creates Better Groups, Firms, Schools, and Societies. Princeton University Press, 2008.

${ }^{8}$ Ottaviano, Gianmarco IP. - Peri, Giovanni: The economic value of cultural diversity: evidence from US cities. Journal of Economic Geography, 2006. 6(1). 9-44.

${ }^{9}$ Putnam, Robert D.: E pluribus unum: Diversity and community in the twentyfirst century the 2006 Johan Skytte Prize Lecture. Scandinavian Political Studies, 2007. 30(2). 137-174.

${ }^{10}$ Granovetter, 1995. 156.
}

REGIO 27. évf. (2019) 1. szám 37-80. 
finom egyensúlyt abban, ahogyan rá- illetve lekapcsolódnak a többség hálózati struktúráiról és normatív szabályrendszeréről. Tim Harford $^{11}$ szerint a körülmények - egy korábbi precízebb megfogalmazásban: „lehetőségstruktúrák”12 - határozzák meg azt, hogy a bonding vagy a bridging típusú kapcsolatok fejlesztése hasznosabb-e, de a legtöbb feladat megoldásához azok kombinálására van szükség.

Az erdélyi magyarok esetében a „lehetőségstruktúrákat” még tovább bővíti az, hogy szoros intézményi kapcsolatban vannak a magyarországi magyarokkal, magyarországi szervezetekkel. Ezek a piacaik bővítésében érdekeltek Magyarország határain túl, a kisebbségi magyarok pedig kifejezetten jól pozícionáltak a két ország közötti (gazdasági) kapcsolatépítésben. Könnyebben híd- vagy brókerszerepbe kerülhetnek, melynek számos előnye van: több és változatosabb, gazdaságilag hasznos összekapcsoló (bridging) kötést, kapcsolatot ápolhatnak, melyeken keresztül értékes piaci információk és lehetôségek birtokába juthatnak; mediátori-integratív funkciókat láthatnak el; erőforrásokat tudnak lehívni mindkét oldalról; hozzájárulhatnak az etnikailag homogén régiók, országok közötti kereskedelem élénkítéséhez. Ez szimbolikusan is egy kifejezetten előnyös helyezkedés: annak a lehetőségét hordozza magában, hogy az eddigi többség-kisebbségi viszony (a románokkal szemben) és a támogató-,,segélyezett" viszony (Magyarországgal szemben) aszimmetriája egy kiegyensúlyozottabb partnerségi viszonnyá minősüljön át.

Románia EU-s csatlakozása ennek a potenciálnak egy óriási lendületet adott azzal, hogy csökkentek az üzletkötés, a kereskedelem, általában pedig mindenféle határokon átnyúló gazdasági együttmüködés tranzakciós és logisztikai költségei. Hasonlóan komparatív előnyt jelenthet az is, hogy az erdélyi magyarok egy jelentős része kettős állampolgár, az EU-s támogatási alapokhoz gyakran két irányból is hozzá lehet férni.

\footnotetext{
${ }^{11}$ Harford, Tim. Messy: How to be creative and resilient in a tidy-minded world. Hachette UK: Little Brown Book Group, 2016. 38-39.

12 Aldrich, Howard E. - Roger, Waldinger: Ethnicity and entrepreneurship. Annual Review of Sociology, Volume 16, issue 1, 1990. 111135.
}

REGIO 27. évf. (2019) 1. szám 37-80. 
Ezeknek a lehetőségeknek az ismeretében a kisebbségi magyarok (és ezen belül a kisebbségi elit) gazdasági szerepét - a különböző gazdaságfejlesztési stratégiák ${ }^{13}$ részeként - többféleképpen vizionálták. Az egyik végleten a leendő kisebbségi autonómiák alapját képező, önálló, párhuzamos, etnikailag integrált enklávégazdaság megteremtőit, kiteljesítőit látják bennük, a másik oldalon az államhatárok és kultúrák mentén szegmentált gazdasági hálózatok összekötöiként, hídembereiként jelennek meg ${ }^{14}$.

Ezektől a szerepelvárásoktól függetlenül az erdélyi magyar vállalkozástörténetekből korábban az derült ki, hogy az etnicitás nem egy központi eleme a vállalkozóvá válásról szóló elbeszéléseknek, ahol pedig megjelenik, ott rendszerint arra utal, hogy szimbolikus tőkeként hasznosítják az egyéni karrierépítésben ${ }^{15}$. Ezzel összhangban a makrostatisztikai vizsgálatok csak elszórtan találtak összefüggést a magyarok aránya és a településszintü vállalkozói aktivitás $^{16}$, illetve a jóléti mutatók között ${ }^{17}$. A lokalitás szerepét komolyan vevő antropológiai-etnográfiai kutatások pedig arra a következtetésre jutottak, hogy a mai erdélyi falvakban a gazdaság etnikai behatárolásáról csak fenntartásokkal lehet beszélni, és hogy az

13 L. pl. Wekerle Terv, Széchenyi terv - Kárpát-medencei térség Gazdaságfejlesztési Övezet alprogram, Nagy Reformkönyv és a Külgazdasági Stratégia vonatkozó fejezetei, A Mikó Imre terv, valamint a Nemzeti Együttmüködés Rendszerének gazdaságfejlesztésre vonatkozó irányelvei.

${ }^{14}$ Papp Z. Attila: Az 1989 utáni romániai, illetve romániai magyar elitek tipológiái és értelmezései. In: Kovách Imre (szerk.): Elitek a válság korában. Magyarországi elitek, kisebbségi magyar elitek. Budapest: Magyar Tudományos Akadémia Politikatudományi Intézet, Magyar Tudományos Akadémia EtnikaiNemzeti Kisebbségkutató Intézet, Argumentum Kiadó, 2011. 463-522.; Papp Z. Attila - Márton János: Párhuzamos világok? Az erdélyi magyar gazdasági és kulturális elit szocio-demográfiai jellemzői. In: Kovách Imre (szerk.): Elitek a válság korában. Magyarországi elitek, kisebbségi magyar elitek. Budapest: Magyar Tudományos Akadémia Politikatudományi Intézet, Magyar Tudományos Akadémia Etnikai-Nemzeti Kisebbségkutató Intézet, Argumentum Kiadó, 2011. 463-522.

15 Kiss Tamás: Vállalkozástörténetek Erdélyben. In: Kovács Éva (szerk.): $A$ gazdasági átmenet etnikai tájképei. Budapest: Teleki László Alapítvány, 2004. $23-128$.

${ }^{16}$ Csata Zsombor: The Social Determinants of Entrepreneurial Activity in Rural Transylvania. Studia Sociologia, 2012/1. 101-124.

${ }^{17}$ Csata Zsombor: Ethnicity and Economy. A Research Agenda for Transylvania. Erdélyi Társadalom (Transylvanian Society), 2015/3. 31-46.

REGIO 27. évf. (2019) 1. szám 37-80. 
„egy etnikai közösséghez való tartozás szervezőeleme lehet a gazdaságnak de... nem is egyetlen, nem is elsődleges és nem is kizárólagos"18. Ugyanakkor az utóbbi időben készült vizsgálatok rámutattak arra ${ }^{19}$, hogy adott politikai, társadalmi környezetben kettős nemzetépítés és erősödő etnopolitikai törekvések közepette az etnicitás mégis fontos konstituáló eleme lehet a gazdaságot szervező struktúráknak, például a fogyasztás mintáinak alakításában.

Ennek az igazolását láthatjuk abban is, hogy az utóbbi évtizedben számos olyan üzleti kezdeményezés, vállalkozás jelent meg, amely termékeivel és szolgáltatásaival kifejezetten kisebbségi magyar fogyasztókat céloz $\mathrm{meg}^{20}$, üzleti diskurzusát/narratíváit magyar kontextusban építi fel, magyar nemzetiségü munkatársakkal dolgozik, magyar üzleti partnerekkel működik együtt. Romániában az EU-s csatlakozást követően a gazdaság müködésének a hatósági felügyelete lazább, a nagyobb piaci dereguláció szabadabb lehetőséget teremt kifejezetten etnikai piacok megteremtésére, etnikai termékek kommodifikációjára és az etnikai hálózatok mentén történő együttmüködésekre is. Ennek a folyamatnak egyre fontosabb szereplöjévé válik a magyarországi kormányzat is azáltal, hogy néhány éve célzottan és jelentős összegekkel támogat határon túli gazdaságfejlesztési programokat is. Ezeknek a hatásairól egyelőre azonban még keveset tudunk.

\section{A vizsgálat kérdései}

A vázolt elemzésekben ${ }^{21}$ közös az, hogy az etnicitást tőkeformákban objektiválódó erőforrásnak tekintik. Az etnicitás egyrészt társadalmi tőke, amely a változatain keresztül - bridging,

18 Szabó Árpád Töhötöm: Etnikai különbségtétel a paraszti gazdaságban. In: Feischmidt Margit (szerk.) Etnicitás: Különbségteremtő társadalom. Budapest: Gondolat - MTA Etnikai-Nemzeti Kisebbségkutató Intézet, 2010. 7.

${ }^{19}$ Szabó Árpád Töhötöm: Dairy Cooperative in the Making: History, Ethnicity and Local Culture in an Economic Enterprise. Erdélyi Tásadalom (Transylvanian Society), 2015/3. 31-46.

${ }^{20}$ Gáll Zoltán: Fából vaskarika? Avagy: lehet-e a székely termék világmárka? Pro Minoritate, 2011/2. 54-71.

${ }^{21}$ A szakirodalom részletesebb összefoglalójáért 1. Csata, 2015.

REGIO 27. évf. (2019) 1. szám 37-80. 
bonding, kognitív, strukturális stb. ${ }^{22}$ - meghatározhatja az egyének társadalmi pozícióit, munkaerőpiaci lehetőségeit és teljesítményét. Másrészt - és ez legalább annyira fontos - az erdélyi magyaroknál az etnicitás és a nyelv elválaszthatatlanul összekapcsolódik egymással (ritka kivétellel a magyarok anyanyelve a magyar), és a román nyelvtudás, mint humán erőforrás szintén befolyásolhatja a munkaerőpiaci és jövedelmi esélyeket.

Korábbi elemzések részletesen dokumentálták ${ }^{23}$, hogy az I. világháború óta eltelt száz évben az erdélyi magyarok társadalmi pozíciói folyamatosan romlottak. Ez a folyamat napjainkban is tart, és szorosan összefügg a magyar etnikumú népesség földrajzi koncentrálódásával azokon a területeken, ahol relatív többségben vannak (Székelyföld, Érmellék stb.) A pozícióvesztést nagyban meghatározza az a tény, hogy ezek kevésbé urbanizált, szegényebb infrastruktúrával rendelkező és gazdaságilag fejletlenebb övezetek. Ebben a dolgozatban ezekkel a makrofeltételekkel, nem áll módunkban foglalkozni. ${ }^{24}$

Számolnunk kell viszont azzal - és ez a vizsgálatunk föhipotézise - hogy ennek a koncentrálódásnak, „tömbösödésnek” a makrokontextustól javarészt független, közvetlen hatása is van az általunk kiemelt tőkefajták termelésére és mennyiségére is. Egyrészt feltehetöleg csökken azoknak az aránya, akik gyakrabban érintkeznek a többségi társadalom tagjaival, a társadalmi interakciók etnikailag homogénebbek lesznek - a putnami szóhasználattal élve csökken a bridging és növekszik a bonding típusú tőke. Másrészt a csökkenő kitettség miatt ezzel együtt romlik a magyarok román nyelvtudása, ami szintén befolyásolhatja a munkaerőpiaci esélyeiket. Végül pedig a magasabb koncentráció növelni fogja az etnikai piacok behatárolhatóságát, ezzel együtt az etnikai marketing hatékonyságát és az etnikai vállalkozások fejlődését - de az etnikai alapú elszigetelődés, a gazdasági enklavizáció veszélyét is.

\footnotetext{
${ }^{22}$ Lancee, Bram: Immigrant performance in the labour market: Bonding and bridging social capital. Amsterdam: Amsterdam University Press, 2012.

23 Kiss Tamás: Etnikai rétegződési rendszer Erdélyben és Romániában. A magyarok társadalmi pozíciói 1. Regio, 2014/2. 187-245.

${ }^{24}$ A terjedelmi korlátok mellett ennek az is az oka, hogy „lehetőségstruktúrák” operacionalizálása nagyon komplex feladat (1. Aldrich-Waldinger, 1990), és egyes dimenziók megragadására nincsenek megbízható adataink.
}

REGIO 27. évf. (2019) 1. szám 37-80. 
Ebben a tanulmányban korábbi kérdőíves vizsgálatok és kvalitatív megfigyelések alapján dokumentáljuk ezeket a változásokat, összekapcsoljuk a tőkefajták volumenét a munkaeröpiaci teljesítménnyel és mérlegeljük a változások várható - parciális, a makrokontextustól elvonatkoztatott - hatásait a romániai magyarok jövőbeli pozícióira és gazdasági helyzetére vonatkozóan. Felhívjuk a figyelmet a bonding típusú társadalmi tőke fontosságára, amely nemcsak a jövedelmek mértékét határozza meg, hanem ragasztóanyaga az erösödő etnikai alapú gazdasági együttmüködésnek is. Ennek két manifesztációjával ismerkedünk meg a tanulmány végén: a fogyasztói etnocentrizmussal és az etnikai vállalkozásokkal.

3. Az erdélyi magyarok román nyelvismeretének és jövedelmének az összefüggései

A 20. század folyamán Erdélyben a használt nyelvek státusa radikálisan megváltozott. A két világháború között, valamint a szocializmusban foganatosított, a magyar nyelv hivatalos és nyilvános használatát jogilag is korlátozó intézkedések miatt az évtizedek során a magyar nyelv megszünt az eltérő nemzetiségüek közötti kommunikáció közös nyelve lenni, lingua francaként már csak nagyon szórványosan és csak a nagyon szük privát szférában bukkan fel. A román nyelvi hegemónia megteremtése a nyilvános szférában a hatalom gyakorlásának a szimbolikus eszközévé vált, erösen aszimmetrikus helyzetbe hozva a többségi és a kisebbségi nyelveket.

A rendszerváltás után Romániában több, a kisebbségi nyelvek védelmében született jogszabály lépett érvénybe, és számos konkrét eredmény is megvalósult az oktatás és az adminisztráció többnyelvüsítésében. Ennek ellenére a hétköznapi interakciókban a magyar nyelv ,jelölt" státusa megmaradt, az etnikailag vegyes területeken a román nyelv használata „alapértelmezett” maradt ${ }^{25}$. A kisebbségiekkel szemben a román nyelv ismerete és használata

\footnotetext{
${ }^{25}$ Brubaker, Robert - Feischmidt Margit - Fox, Jon - Grancea, Livia: Nationalist Politics and Everyday Ethnicity in a Transylvanian Town. Princeton University Press, 2018.
}

REGIO 27. évf. (2019) 1. szám 37-80. 
továbbra is kizárólagos elvárás ${ }^{26}$. Annak ellenére, hogy a román nyelv primátusát és szimbolikus dominanciáját az erdélyi magyarok többsége legitimnek tartja ${ }^{27}$, az aszimmetrikus kétnyelvüségnek ez az állapota esélyhátrányt eredményezhet a kisebbségi anyanyelvüek körében. Ezek a hátrányok abból fakadnak, hogy a közös nyelv megtanulásának jelentős költségei és alternatív költségei vannak, a magyaroknak a formális kommunikáció többletkiadásokkal jár (például a fordítási költségek miatt), a román nyelvü társalgásban pedig legitimációs és retorikai hátrányba kerülhetnek. ${ }^{28}$

Ezek az esélyhátrányok még nagyobbak lehetnek, ha a román nyelvet nem sikerül a megfelelő mértékben elsajátítani. Az 1. táblázatban közölt adatok szerint ez a veszély az erdélyi magyarok körében egyre inkább fennáll, különösen a fiataloknál jelent növekvő problémát. ${ }^{29}$ Gyorsan csökken azoknak a száma, akik hibátlanul beszélik a románt, és növekszik azoké, akik nem beszélnek nagyon jól. ${ }^{30}$

${ }^{26}$ Kiss Tamás: Increasing Marginality, Ethnic Parallelism and Asymmetric Accommodation. Social and Political Processes Concerning the Hungarian Community of Transylvania. Minority Studies, 2015/1. 33-69.

${ }^{27}$ Horváth István: Az erdélyi magyarok kétnyelvüsége: nyelvmentés és integráció között. Erdélyi Társadalom, 2003. 1(1). 20.

${ }^{28}$ Grin, Francois. On the costs of cultural diversity. In: Van Parijs, Philippe (ed.): Cultural Diversity vs. Ethnic Solidarity. Bruxelles: DeBoeck - Larcier, 2004. 198-199.; Csata Zsombor: Reflections on the economic aspects of multilingualism in Transylvania. Belvedere Meridionale, 2016. 28(2). 53.

${ }^{29}$ Az Erdélyi Fiatalok 2008 és 2013 vizsgálatokat a Nemzeti Kisebbségkutató Intézet készítette. A véletlen minta 1197, illetve 1224 főből állt, és az erdélyi magyar 15-29 éves fiatalokra volt reprezentatív nemek, régiók, településtípusok és korcsoportok szerint.

${ }^{30}$ A román nyelvi kompetenciák ahhoz mérten is nagyon alacsonyak, hogy az erdélyi magyar diákok az iskolakezdéstől az érettségiig heti 4 órában tanulják a román nyelv és irodalmat, ezen felül pedig - egy középiskolás mérés szerint átlagosan további heti 3 órát foglalkoznak a házi feladatokkal, ami alacsonyabb iskolai szinteken még több is lehet. Ez azt jelenti, hogy egy érettségiig eljutott átlagos diák - csak a formális oktatásban - 2350 órát foglalkozik a romántanulással. Közérthetöbben: heti negyven órában, „fóállásban”, másfél éven keresztül csak románul tanul. A vizsgálat a BBTE Szociológia Intézete és a Max Weber társadalomkutató Központ (Kolozsvár) irányításával készült 2015-ben. A véletlen minta 1109 főből állt, és az erdélyi magyar középiskolásokra volt reprezentatív területi megoszlás, az iskolák és az osztályok profilja, valamint az évfolyamok szerint.

REGIO 27. évf. (2019) 1. szám 37-80. 
1. táblázat. Melyik kijelentés érvényes az Ön esetében a román nyelv ismeretét illetően? (15-29 év közötti erdélyi magyar fiatalok, \%)

\begin{tabular}{|l|c|c|}
\hline & $\begin{array}{c}\text { Erdélyi } \\
\text { fiatalok } \\
\mathbf{( 2 0 0 8 )} \\
\mathbf{N = 1 1 9 7}\end{array}$ & $\begin{array}{c}\text { Erdélyi } \\
\text { fiatalok } \\
\mathbf{( 2 0 1 3 )} \\
\mathbf{N = 1 2 2 4}\end{array}$ \\
\hline Anyanyelvem & 1,3 & 1,6 \\
\hline Tökéletesen beszélek & 40 & 26,2 \\
\hline $\begin{array}{l}\text { Nagyon jól beszélek, de érezhetö } \\
\text { akcentussal }\end{array}$ & 33,4 & 34,6 \\
\hline $\begin{array}{l}\text { Nem beszélek nagyon jól, de esetek } \\
\text { többségében meg tudom értetni magam }\end{array}$ & 17,6 & 28,8 \\
\hline $\begin{array}{l}\text { Nagyjából értek és nehézségekkel meg } \\
\text { tudom értetni magam }\end{array}$ & 6,1 & 7,3 \\
\hline Alig egy pár szót tudok & 1,5 & 1,4 \\
\hline Egy szót sem ismerek & 0,2 & 0,2 \\
\hline
\end{tabular}

Forrás: Erdélyi Fiatalok 2008 és 2013 vizsgálatok

Egy 2009-ben készült kutatás szerint ${ }^{31}$ azok a romániai magyarok, akik jól beszélnek románul, 34 százalékkal többet keresnek azokhoz képest, akik nem beszélnek jól, vagy egyáltalán nem beszélik a többség nyelvét. A különbség jelentős részét azonban nem az eltérő nyelvtudás magyarázza, hanem azok a tényezők, amelyek ezzel összefüggenek: a válaszadók neme, iskolai végzettsége és lakhelye (városi vagy falusi, székelyföldi-e vagy sem). A tisztánlátás végett ezeket a tényezőket egy közös lineáris regressziós modellbe vontuk be (2. táblázat). Ennek eredménye azt mutatja, hogy a román nyelvtudás hiánya akkor is kedvezőtlenül befolyásolja a jövedelmet, ha az említett tényezőket kontroll alatt tartjuk. Ráadásul ez a hatás a magasan képzettek körében nem érvényesül, jövedelemkülönbséget eredményez viszont azok körében, akik legfeljebb érettségivel

${ }^{31}$ Az Életünk Fordulópontjai 2. kérdőíves vizsgálatra 2008-2009-ben került sor a KSH Népességtudományi Kutató Intézet (Budapest), a Nemzeti Kisebbségkutató Intézet (Kolozsvár) és a Max Weber Társadalomkutató Központ (Kolozsvár) irányításával. A 4017 fős minta nemek, korcsoportok és területi megoszlás szerint reprezentatív az erdélyi magyar népességre. A maximális mérési hiba 95 százalékos valószínüség mellett $1,5 \%$.

REGIO 27. évf. (2019) 1. szám 37-80. 
rendelkeznek. A román nyelvtudás hiánya a képzetlenebbek körében okoz a leginkább jövedelemhátrányt, tovább rontva a leszakadók helyzetét.

2. táblázat Lineáris regressziós modell a jövedelem becslésére erdélyi magyarok (standardizált regressziós együtthatók, N=1651)

\begin{tabular}{|c|c|c|c|}
\hline & Erdély & Székelyföld & $\begin{array}{c}\text { Székelyföldön } \\
\text { kívüli erdélyi } \\
\text { régiók }\end{array}$ \\
\hline Férfi & $\begin{array}{c}0,199 * \\
* *\end{array}$ & $0,115 * *$ & $0,268 * * *$ \\
\hline $\begin{array}{l}\text { középiskolai } \\
\text { végzettség (elemi } \\
\text { és alapszintü } \\
\text { végzettséghez } \\
\text { viszonyítva) }\end{array}$ & $\begin{array}{c}0,105 * \\
*\end{array}$ & $0,084 *$ & $0,119 * *$ \\
\hline $\begin{array}{l}\text { felsőfokú } \\
\text { végzettség (elemi } \\
\text { és alapszintű } \\
\text { végzettséghez } \\
\text { viszonyítva) }\end{array}$ & $\begin{array}{c}0,300 * \\
* *\end{array}$ & $0,244 * * *$ & $0,333 * * *$ \\
\hline városi lakhely & $\begin{array}{c}0,102 * \\
*\end{array}$ & $0,093 *$ & $0,107 * *$ \\
\hline $\begin{array}{l}\text { székelyföldi } \\
\text { lakhely }\end{array}$ & $\begin{array}{c}- \\
0,076^{*} \\
*\end{array}$ & - & - \\
\hline $\begin{array}{l}\text { jó román } \\
\text { nyelvtudás }\end{array}$ & $\begin{array}{c}0,085^{*} \\
* \\
\end{array}$ & $0,067 *$ & $0,108 * *$ \\
\hline $\begin{array}{l}\text { Determinációs } \\
\text { együttható ( } R \\
\text { négyzet) }\end{array}$ & 0,169 & 0,091 & 0,215 \\
\hline
\end{tabular}
szignifikáns hatásokat közöltük.

Forrás Életünk Fordulópontjai 2. vizsálat (2009)

A megfelelő román nyelvtudás hiányából fakadó munkaerőpiaci és jövedelmi különbségeket korábbi kutatások is igazolják. Egy 2008-as

REGIO 27. évf. (2019) 1. szám 37-80. 
felmérés alapján például Horváth István is azt találta ${ }^{32}$, hogy a magyarok körében szignifikáns kapcsolat van a román nyelv használatának gyakorisága és a vagyoni-jövedelmi helyzet között (háztartás ellátottsága, jövedelem nagysága), amit annak a jeleként értelmez, hogy a többségi nyelv ismerete a mobilitás egyik fontos eszköze az erdélyi magyarok körében. A Babeș-Bolyai Tudományegyetem végzősei körében készült vizsgálatban kimutattuk $^{33}$, hogy a magyar diplomások a románokhoz képest szignifikánsan kisebb arányban helyezkednek el a versenyszférában, és inkább dolgoznak olyan állami és önkormányzati állásokban, ahol a magyar nyelv használata követelmény (kultúra és oktatás), vagy törvényileg garantált (különböző hivatalok). A fiatalok karriertervezéséröl szóló elemzésében Dániel Botond ezzel kapcsolatban kimutatta, hogy az erdélyi magyar fiatalok (ezen belül pedig különösen a székelyföldiek) ugyan nem zárkóznak el attól, hogy „román alkalmazóhoz kerüljenek, román munkatársakkal dolgozzanak együtt, azonban sokkal szívesebben helyezkednének el magyar munkakörnyezetben, komfortosabban éreznék magukat a mindennapi munkavégzés során." ${ }^{34}$ Jó okunk van feltételezni, hogy a magyar fiatalok közül sokan a hiányosnak vélt nyelvtudásuknak köszönhetően ,alultervezik” a karrierjüket, alacsonyabb fizetéssel is beérik, cserében azért, hogy magyar vagy többségében magyar nyelvi környezetben dolgozhassanak. Kínálati oldalon hasonló érvelésekkel találkozott Geambaşu Réka is az informatikai vállalkozókkal készült interjúiban, ahol többen arról számoltak be, hogy magyar fejlesztőket olcsóbban lehet alkalmazni, mert közülük sokak számára fontos, hogy anyanyelvi környezetben dolgozzanak. Egy magas hozzáadott értéket termelö, erősen tudásalapú iparágban fontos a ,jó hangulat", ami „,egyebek mellett egyebek mellett az etnikailag homogén, magyar

32 Horváth István: Elemzések a romániai magyarok kétnyelvüségéröl. Mühelytanulmányok a romániai kisebbségekröl 8. Kolozsvár: Nemzeti Kisebbségkutató Intézet, 2008.

33 Csata Zsombor - Dániel Botond - Pop, Carmen: Pályakezdő fiatalok a munkaerőpiacon. Erdélyi Társadalom, 2006. Volume 4, issue 1. 7-27.

34 Dániel Botond: Erdélyi magyar fiatalok jövőterveinek, munkaerő-piaci helyzetének, etnikai fogyasztásának vizsgálata. In: Szabó Andrea - Bauer Béla Pillók Péter (szerk.): Mozaik 2011 - Magyar fiatalok a Kárpát-medencében. Kutatási jelentés. Szeged-Budapest: Belvedere Meridionale - Nemzeti Család- és Szociálpolitikai Intézet, 2013. 196.

REGIO 27. évf. (2019) 1. szám 37-80. 
munkaközösséget is jelenti, vagyis megfordítva, egy etnikailag heterogén munkaközösséget a munkavállalók nem tudnának jó hangulatúnak tekinteni. Ebben az értelemben a munkaadók arra irányuló törekvése, hogy magyar szoftverfejlesztőket vegyenek fel, gazdaságilag is racionális." 35 Ezek után teljesen ésszerü az is, hogy ezek a cégek a munkaerö-rekrutációban is elsődlegesen magyar hálózatokat használjanak.

Bár megbízható kvantitatív vizsgálat ebben a témában még nem készült, az említett példák alapján eléggé valószínü, hogy a munkaerőpiacon a nyelvtudás és a nyelvi környezet is egy erős szelekciós szempont, aminek a jelentőségét - véleményem szerint az eddigi kutatások jelentősen alábecsülték. A nyelvtudás meghatározza az egyének karrierorientációját, és markánsabban jelen van a munkaadók mérlegeléseiben, mint ahogy eddig gondoltuk.

Chiswick és Miller ${ }^{36}$ szerint a többségi nyelv ismeretét három tényező határozza meg: a nyelvi kitettség (beleértve a média szerepét), a nyelvtanulás hatékonysága és a nyelvtanuláshoz kapcsolódó gazdasági ösztönzők. A nyelvi kitettség erősen összefügg azzal, hogy mennyire intenzív a többséggel való érintkezés, és milyen gyakoriak a románokkal való kapcsolatok. A magyarok növekvő földrajzi koncentrációja miatt azt feltételezzük, hogy a jövőben még alacsonyabb lesz az interakciósürüség a románok és a magyarok között, ez pedig azt fogja jelenteni, hogy egyre kevesebben fognak jól tudni románul - feltéve, ha az oktatás hatékonysága és a román nyelv iránti keresletösztönzők ${ }^{37}$ nem változnak. Azt valószínüsítjük tehát,

\footnotetext{
${ }^{35}$ Geambașu Réka: „A kódolás élvezete”. A kolozsvári programozók. Kézirat, 2017. 12.

36 Chiswick, Barry R. - Miller, Paul W.: The economics of language: International analyses. Routledge, 2007. 6-10.

37 A román nyelvoktatás gyenge hatékonyságával és a román tanulásának motivációival kapcsolatban 1. Szilágyi N. Sándor: De ce nu-şi pot însuşi copiii maghiari limba română în şcoală? Altera, 1998/7.; Tódor Mária Erika: A kódváltás és az aszimmetrikus kétnyelvüség nyelvpedagógiai összefüggései. Magyar Pedagógia, 2005/105. 41-58.; Benő Attila: Hogyan tanulják a magyar gyerekek a román nyelvet az erdélyi iskolákban? Problémák és lehetőségek, Székelyföld, 2012. május. A médiakitettséggel kapcsolatban fontos megjegyezni, hogy az ezredfordulót követően jelentősen átalakultak az erdélyi magyarok médiafogyasztási szokásai. Egyre többen kapcsolódtak be a magyarországi magyar médiatérbe, a román nyelvü médiafogyasztás pedig csökkent, 1. Kiss Tamás: Az erdélyi magyarok médiafogyasztása. Erdélyi Társadalomtudományi
}

REGIO 27. évf. (2019) 1. szám 37-80. 
hogy intézményi körülmények és a makrokontextus változatlansága mellett az erdélyi magyarok jövedelemhátránya a romló román nyelvtudás miatt tovább fog növekedni.

\section{A társadalmi töke és a munkaeröpiaci teljesitmény kapcsolata}

A többségi nyelv elsajátításában és eredményes használatában fontos szerepe van a románokkal való kapcsolatoknak. Számtalan korábbi elemzés alapján a kapcsolatokról viszont úgy gondoljuk, hogy a nyelvtudástól független, önálló hatásuk is van a munkaerőpiaci esélyekre ${ }^{38}$. Ebben az alfejezetben a tágabban értelmezett társadalmi töke hatásait vizsgáljuk az erdélyi magyarok jövedelmi helyzetére.

A társadalmi tőke jelentésének, operacionalizálásának, eredetének, formáinak és következményeinek a vizsgálata könyvtárnyi szakirodalmat tesz ki. A terjedelmi korlátok miatt itt nincs lehetőségünk egy kimerítően részletes, az erdélyi magyarok sajátos helyzetéhez igazított konceptualizálást és operacionalizálást módszeresen végigvinni. Ehelyett kiválasztottunk egy olyan kortárs elemzést, a Bram Lancee-ét, ${ }^{39}$ amely célkitüzéseiben, módszereiben és adatigényében a leginkább hasonlít a mi szándékainkhoz ráadásul a szakirodalomnak egy kitünően fókuszált áttekintését is adja.

Akárcsak mi, az etnicitást Lancee is egy egyéni erőforrásnak tekinti, az etnikailag homogén és heterogén kapcsolatok (társadalmi tőke) és a nyelvi kompetenciák (humán tőke) hatását vizsgálja az egyének munkaerőpiaci teljesítményére (munkanélküliségi kockázat, munkahelyi státus és jövedelem) ${ }^{40}$. A bonding és a bridging

Lexikon. Kolozsvár: Jakabffy Elemér Alapítvány - Transindex. 2015. A tömbben élök pedig az átlaghoz képest is egyre kevesebb román médiatartalmat követnek, a kitettség tehát ebben az értelemben is csökken.

${ }^{38}$ Nagy bánatunkra a nyelvtudás és a társadalmi tőke hatásait nem tudjuk egy közös modellben megvizsgálni, sajnos nem készült olyan kérdőíves kutatás, ahol ezek a változók együtt szerepeltek volna.

${ }^{39}$ Lancee, 2012.

${ }^{40}$ Hogy egyéni vagy közösségi erőforrásként tekintünk a társadalmi tőkére, annak most másodlagos jelentősége van. Lancee vizsgálata a hollandiai és németországi bevándorlókra vonatkozik, fogalmi hálója és a kutatás analitikus kerete viszont

REGIO 27. évf. (2019) 1. szám 37-80. 
tőkefajtákat nagyjából az etnikumok közötti, illetve az etnikumon belüli kapcsolatoknak felelteti meg. Mivel az etnikai kisebbség és a többség egyaránt birtokolhatnak az egyén munkaerőpiaci sikere szempontjából hasznos erőforrásokat, a bonding nem kizárólag a „boldogulást” (get by) és bridging nem mindig a „haladást” (get ahead) segíti, mint ahogy azt gyakran feltételezik ${ }^{41}$. Lancee mindkét változat esetében különbséget tesz a társadalmi tőke strukturális és kognitív összetevői között. Az előbbiek magukat a kapcsolatokat, „huzalokat” (wires) jelentik, azok kiterjedtségét és intenzitását, utóbbiak pedig a „csomópontokat”, olyan, „a támogatás, a viszonosság és a bizalom percepciójához kapcsolódó attitűdöket és értékeket, amelyek elősegítik az erőforrások cseréjét" ${ }^{42}$.

A bonding társadalmi tőke sürüre szőtt, személyes kapcsolatokat és erős személyközi bizalmat (thick trust) takar. A bridging ezzel szemben „strukturális lyukakban”43 létrejövő ritkább és lazább kötéseket jelent, amelyek viszont összekötik a különböző szocioökonómiai kategóriák mentén kialakult kisvilágokat (osztály, korcsoportok, etnikum stb.) Kognitív összetevője a ,thin trust”, amely nem annyira a személyekbe, hanem a modern társadalom intézményeibe vetett bizalomnak (confidence) és a durkheimi értelemben vett organikus szolidaritásnak feleltethető meg.

A társadalmi tökefajták Lancee-féle modelljét valamelyest módosítottuk azzal, hogy a klasszikus granovetteri definíció mentén az „erős” és a ,gyenge” kötéseket is beemeltük a modellünkbe ${ }^{44}$. Ezt némileg leegyszerüsítve az „erős” kötéseknek a családi, a „gyenge” kapcsolatoknak pedig a családon kívülröl mobilizálható nexusokat

öshonos, történelmi kisebbségek helyzetének a vizsgálatára különösebb fenntartások nélkül alkalmas. L. Lance, 2012.

${ }^{41}$ Narayan, Deepa: „Bonds and bridges: social capital and poverty.” Social capital and economic development: well-being in developing countries. Northampton, MA: Edward Elgar, 2002. 58-81.; Orbán Annamária - Szántó Zoltán: Társadalmi tőke. Erdélyi Társadalom, 2005. 3(2). 55-70.

${ }^{42}$ Lancee, 2012. 18.

${ }^{43}$ Burt, Ronald S.: Structural Holes: The Social Structure of Competition. Cambridge: Harvard University Press. 1995.

${ }^{44}$ Granovetter, Mark: The strength of weak ties. American Journal of Sociology, 1973. 78(6). 1360-1380.

REGIO 27. évf. (2019) 1. szám 37-80. 
tekintettük. Az elemzésben használt dimenziókat az alábbi táblázat foglalja össze:

3. táblázat. Az egyéni (individual) társadalmi tőke összetevői a kisebbségi magyaroknál

\begin{tabular}{|c|l|l|l|}
\hline összetevők & \multicolumn{1}{|c|}{ típusok } & \multicolumn{1}{|c|}{ erős } & \multicolumn{1}{c|}{ gyenge } \\
\hline Strukturális & bridging & román családi kapcsolatok & $\begin{array}{l}\text { családon kívüli } \\
\text { román } \\
\text { kapcsolatok }\end{array}$ \\
\cline { 2 - 5 } & bonding & magyar családi kapcsolatok & $\begin{array}{l}\text { családon kívüli } \\
\text { magyar } \\
\text { kapcsolatok }\end{array}$ \\
\hline \multirow{2}{*}{ Kognitív } & bridging & bizalom a családban (vegyes családok) & $\begin{array}{l}\text { általánosított } \\
\text { bizalom, bizalom } \\
\text { a románokban }\end{array}$ \\
\cline { 2 - 5 } & bonding & bizalom a családban (magyar családok) & $\begin{array}{l}\text { bizalom a } \\
\text { magyarokban }\end{array}$ \\
\hline
\end{tabular}

Saját elemzésünkben elöször ezeknek a társadalmi tőkefajtáknak a változását vizsgáljuk az erdélyi magyarok körében, egy 2000-ben és egy 2012-ben készült kérdöíves felmérés alapján. ${ }^{45}$

A társadalmi töke strukturális összetevöit a két vizsgálatban egyegy hálózati kérdéssoron keresztül mérték, amely arra kérdezett rá, hogy az alanyok a különböző élethelyzetekben számíthatnak-e más emberek segítségére, illetve vannak-e körülöttük olyan személyek, akikkel barátkozni szoktak, társas tevékenységben közösen részt

45 A „Társadalmi kapcsolathálók Erdélyben” kutatás a Max Weber Társadalomkutató Központ (Kolozsvár) keretében készült 2000-ben, Veres Valér egyéni projektjeként (az adatok részletes feldolgozásához 1. Veres 2005). Az Erdélyre kiterjedő, személyes megkérdezésen alapuló kérdőíves mérés magyar mintája 925 esetet tartalmaz. A 2012-ben készült CCCDC-RIRNM kutatást a Trans-Objective Consulting intézet végezte a Nemzeti Kisebbségkutató intézet munkatársainak a bevonásával (kutatásvezető: Kiss Tamás). Ennek keretében 1192 magyar személy került lekérdezésre. Mindkét minta nemek, korcsoportok és területi megoszlás szerint reprezentatív az erdélyi magyar népességre. A maximális mérési hiba 95 százalékos valószínüség mellett 3,2, illetve 2,8 százalék. A szerző ezúttal is kifejezi köszönetét a kutatás koordinátorainak, hogy az adatokat felhasználhatta az elemzéshez.

REGIO 27. évf. (2019) 1. szám 37-80. 
vesznek. Mi ezek közül összesen öt ilyen szituációt vizsgáltunk ${ }^{46}$, mindegyikhez három-három személyt lehetett felsorolni, ennek megfelelően a kapcsolatok száma 0 és 15 között változhatott. A kérdöívben rögzítették ezeknek a viszonyoknak a természetét (család/első fokú rokon, más rokon, szomszéd, barát, ismerős), a kapcsolatszemély nemét, életkorát, végzettségét és nemzetiségét. A 3. táblázatban bemutatott operacionalizálásnak megfelelően mi a viszony természetére és a kapcsolatszemély nemzetiségére vonatkozó adatokat dolgoztuk fel.

4. táblázat. A társadalmi kapcsolatok kiterjedtsége az erdélyi magyarok körében $(2000,2012)$

\begin{tabular}{|c|c|c|c|c|}
\hline & \multicolumn{2}{|c|}{ TKE $2000(\mathrm{~N}=892)$} & \multicolumn{2}{|c|}{ CCCDC-RIRNM $2012(\mathrm{~N}=1192)$} \\
\hline & átlag & szórás & átlag & Szórás \\
\hline kapcsolatok száma összesen & 4.65 & 3.06 & 3.92 & 3.06 \\
\hline családi kapcsolatok & 1.28 & 1.50 & 1.28 & 1.57 \\
\hline családon kívüli kapcsolatok & 3.37 & 2.65 & 2.64 & 2.60 \\
\hline magyar kapcsolatok & 3.90 & 3.02 & 3.39 & 2.83 \\
\hline román kapcsolatok & 0.35 & 0.90 & 0.43 & 1.19 \\
\hline családon belüli magyar kapcsolatok & 1.10 & 1.43 & 1.19 & 1.51 \\
\hline családon kívüli magyar kapcsolatok & 2.78 & 2.54 & 2.20 & 2.37 \\
\hline családon belüli román kapcsolatok & 0.04 & 0.26 & 0.06 & 0.38 \\
\hline családon kívüli román kapcsolatok & 0.30 & 0.82 & 0.30 & 0.91 \\
\hline
\end{tabular}

Forrás: TKE 2000 és CCCDC-RIRNM 2012 vizsgálatok

\footnotetext{
${ }^{46}$ A TKE 2000 vizsgálat nyolc ilyen élethelyzetet vizsgált, az Etnobarométer 2012 csupán ötöt. Az összehasonlíthatóság kedvéért csak a mindkettőben közös szituációkra vonatkozó adatokat dolgoztuk fel. Ezek az alábbiak voltak: 1. „Ön volt-e vendégségben valakinél, vagy fogadott-e vendéget az elmúlt 3 hónapban?”, 2. „Van-e olyan személy, vannak-e olyan személyek, akikkel közösen eljárnak szórakozni (bárokba, kirándulni, színházba, sporteseményekre stb.)?”, 3. „A családtagokon kívül szokott-e ön időnként egészen személyes, bizalmas dolgokról, problémákról elbeszélgetni?”, 4. „Tegyük fel, hirtelen pénzre lenne szüksége. Vannak-e olyanok, akiktől ilyenkor kölcsönkérne?”, 5. „Időnként szükségünk van az életben valami tanácsra, hivatalos ügyben segítségre, befolyásra. Vannak olyan emberek az ön környezetében, akikre ilyenkor számíthat?"
}

REGIO 27. évf. (2019) 1. szám 37-80. 
Az eredmények azt mutatják, hogy 2012-ben az erdélyi magyarok átlagosan 4-4,5 mozgósítható kapcsolatot említettek ${ }^{47}$, ezek közül csupán minden tizedik etnikailag heterogén, azaz román személlyel létrejött kapcsolat. Minden ötödik magyar embernek van „használható" román kapcsolata, ez a szórványtelepüléseken értelemszerủen magasabb (37 százalék), a tömbben alacsonyabb ( 9 százalék). A kapcsolatok egyharmada családon belülre, kétharmada családon kívülre mutat. Családon belül ritkábbak az etnikailag vegyes kapcsolatok (5 százalék), családon kívül viszont gyakoribbak (11,4 százalék).

A két felvétel közötti időszak változásait illetően azt feltételeztük, hogy a magyarok „tömbösödésével” párhuzamosan egyre kevesebb magyarnak lesznek román kapcsolatai. Ezt azonban nem tudtuk ellenőrizni, mert a magyarok településenkénti arányát tekintve a két minta nagyon hasonlít egymásra, a 2012-es adatokban a szórványosodás nem érhető tetten. Ezért van az, hogy 2000-ben is ugyanúgy 20 százalékra tehető azoknak az aránya, akik a felsorolt élethelyzetekben románok segítségét (is) kérték. A két felmérés között eltelt 12 évben egyedül a családon kívüli magyar kapcsolatok száma csökkent (és ezzel együtt a kapcsolatok átlagos száma is), minden egyéb mutató viszont változatlan maradt.

5. táblázat. A román kapcsolatokkal rendelkezők aránya, a magyarok aránya szerint elkülönített településkategóriákban

\begin{tabular}{|l|c|c|}
\multicolumn{2}{|c}{$(2000,2012$, százalékok) } \\
\hline szórvány (20\% alatt) & $\begin{array}{c}\text { TKE 2000 } \\
(\mathrm{N}=924)\end{array}$ & $\begin{array}{c}\text { CCCDC-RIRNM } 2012 \\
(\mathrm{~N}=1029)\end{array}$ \\
\hline kisebbség $(20-39,9 \%)$ & 38,7 & 37,1 \\
\hline paritás (40-59,9\%) & 26,0 & 28,1 \\
\hline magyar többség (60-89,9\%) & 15,0 & 13,9 \\
\hline magyar dominancia (90\% fölött) & 15,2 & 11,9 \\
\hline Erdély összesen & 6,9 & 8,6 \\
\hline
\end{tabular}

Forrás: TKE 2000 és CCCDC-RIRNM 2012 vizsgálatok

\footnotetext{
${ }^{47}$ Az hajszálpontosan azért nem megállapítható, mert nem tudni, hogy a mintának az a 15 százaléka (187 személy), aki egyetlen nexust sem említett, az azért nem említett-e, mert tényleg nincs neki ilyen, vagy pedig egyszerüen nem válaszolt a kérdésre. A későbbi regressziós modelljeinket a teljes mintára futtattuk le.
}

REGIO 27. évf. (2019) 1. szám 37-80. 
A társadalmi tőke kognitív összetevőjének a vizsgálatára még korlátozottabbak voltak a lehetőségeink, a 2012-es mérés csak az általánosított bizalmat és az egyes etnikai csoportokkal szembeni bizalmat mérte, a 2000-es kutatás pedig egyáltalán nem tartalmazott a bizalomra vonatkozó kérdéseket. Az eredmények azt mutatják (6. táblázat), hogy az erdélyi magyarok körben nagyon alacsony az általánosított bizalom, és a magyarokhoz képest jóval kevesebben bíznak a románokban.

6. táblázat. A bizalom mértéke az erdélyi magyarok körében ${ }^{48}$ (CCCDC-RIRNM 2012,\%)

\begin{tabular}{|l|l|}
\hline általánosított bizalom & 8,1 \\
\hline bizalom a magyarokban & 79,9 \\
\hline bizalom a románokban & 56,3 \\
\hline
\end{tabular}

Forrás: CCCDC-RIRNM 2012 vizsgálat

Második lépésben megvizsgáltuk, hogy a kapcsolatok kiterjedtsége és etnikai jellege összefüggésben van-e az alanyok jövedelmi helyzetével. Bár a kauzalitás iránya nem egyértelmü, a szakirodalom alapján azt feltételeztük, hogy minél kiterjedtebb az egyén kapcsolathálója és minél inkább tartalmaz a családon és az etnikai csoporton kívüli kötéseket, annál valószínübb, hogy jobban keres, és kevésbé van kitéve a szegénység kockázatának is. Hasonlóan pozitív hatást kapcsoltunk a bizalomhoz is. A hipotézisek tesztelésére regresszióelemzéseket végeztünk, ahol elöször csupán a társadalmi tőke mutatóit emeltük be a modelljeinkbe. A második, bővített változatot viszont kiegészítettük azokkal a szocio-

48 A bizalom változatait az alábbi kérdéssekkel mértük: „Általában véve, Ön szerint a legtöbb emberben meg lehet bízni, vagy inkább óvatosnak kell lenni az emberi kapcsolatok terén?” (Általában a legtöbb emberben megbízhatunk / Jobb, ha óvatosabbak vagyunk az emberekkel való kapcsolatainkban), illetve „Ön mennyire bízik a magyarokban/románokban?” (teljesen megbízik bennük, inkább megbízik bennük, nem nagyon bízik bennük). A táblázatban közölt százalékok az affirmatív válaszok arányát jelölik.

REGIO 27. évf. (2019) 1. szám 37-80. 
demográfiai kontrollváltozókkal, amelyek maguk is hatással lehetnek a jövedelmi helyzetre. ${ }^{49}$

7. táblázat. A háztartások egy főre jutó ekvivalens jövedelmét becslő lineáris regressziós modell (RON - 2012)

\begin{tabular}{|c|c|c|c|c|c|c|c|}
\hline \multirow{2}{*}{ Változó } & \multirow{2}{*}{ Változóértékek } & \multicolumn{3}{|c|}{ Egyszerü modell } & \multicolumn{3}{|c|}{ Bővített modell } \\
\hline & & B & std. $h$. & szign. & B & std. $h$. & szign. \\
\hline \multicolumn{2}{|c|}{$\begin{array}{l}\text { Determinációs együttható } \\
\text { (Igazított R négyzet) }\end{array}$} & \multicolumn{3}{|c|}{0.036} & \multicolumn{3}{|c|}{0.327} \\
\hline \multicolumn{2}{|c|}{ Konstans } & 614.522 & 33.966 & .000 & 971.861 & 65.850 & .000 \\
\hline \multirow[t]{4}{*}{$\begin{array}{l}\text { Strukturális } \\
\text { társadalmi } \\
\text { tőke }\end{array}$} & $\begin{array}{l}\text { családon belüli } \\
\text { magyar } \\
\text { kapcsolatok }\end{array}$ & -14.918 & 8.966 & .096 & -11.962 & 7.780 & .124 \\
\hline & $\begin{array}{l}\text { családon kívüli } \\
\text { magyar } \\
\text { kapcsolatok }\end{array}$ & 33.909 & 5.849 & .000 & 10.336 & 5.755 & .073 \\
\hline & $\begin{array}{l}\text { családon belüli } \\
\text { román } \\
\text { kapcsolatok }\end{array}$ & 5.382 & 36.765 & .884 & -12.043 & 31.387 & .701 \\
\hline & $\begin{array}{l}\text { családon kívüli } \\
\text { román } \\
\text { kapcsolatok }\end{array}$ & 23.377 & 15.506 & .132 & -17.265 & 14.185 & .224 \\
\hline \multirow{3}{*}{$\begin{array}{l}\text { Kognitív } \\
\text { társadalmi } \\
\text { tőke }\end{array}$} & $\begin{array}{l}\text { általánosított } \\
\text { bizalom }\end{array}$ & 27.948 & 50.456 & .580 & -51.775 & 43.026 & .229 \\
\hline & $\begin{array}{l}\text { bizalom a } \\
\text { magyarokban }\end{array}$ & 44.889 & 31.571 & .155 & 55.950 & 27.223 & .040 \\
\hline & $\begin{array}{l}\text { bizalom a } \\
\text { románokban }\end{array}$ & 58.677 & 39.085 & .134 & 15.131 & 34.534 & .661 \\
\hline \multirow[t]{4}{*}{ Korcsoportok } & 20-29 év & & & & & & \\
\hline & 15-19 év & & & & 85.774 & 81.930 & .295 \\
\hline & 30-59 év & & & & 57.728 & 39.385 & .143 \\
\hline & $60+$ & & & & 232.341 & 55.660 & .000 \\
\hline \multirow[t]{2}{*}{ Nem } & Férfi & & & & & & \\
\hline & Nö & & & & -62.225 & 24.682 & 012 \\
\hline
\end{tabular}

49 Mivel a TKE 2000 kutatás nem tartalmazott bizalommal kapcsolatos kérdéseket, a modelleket csupán a CCCDC-RIRNM 2012 kutatás adatain futtattuk le.

REGIO 27. évf. (2019) 1. szám 37-80. 


\begin{tabular}{|c|c|c|c|c|c|c|c|}
\hline \multirow{2}{*}{ Változó } & \multirow{2}{*}{ Változóértékek } & \multicolumn{3}{|c|}{ Egyszerü modell } & \multicolumn{3}{|c|}{ Bővített modell } \\
\hline & & B & std. h. & szign. & B & std. $h$. & szign. \\
\hline \multirow[t]{3}{*}{$\begin{array}{l}\text { Családi } \\
\text { állapot }\end{array}$} & $\begin{array}{l}\text { Hajadon, } \\
\text { nőtlen }\end{array}$ & & & & & & \\
\hline & $\begin{array}{l}\text { Házas, vagy } \\
\text { élettársi } \\
\text { viszonyban él }\end{array}$ & & & & $\begin{array}{c}- \\
107.257\end{array}$ & 37.942 & .005 \\
\hline & Elvált, özvegy & & & & $\begin{array}{c}- \\
205.215 \\
\end{array}$ & 50.218 & .000 \\
\hline \multirow{5}{*}{$\begin{array}{l}\text { Iskolai } \\
\text { végzettség }\end{array}$} & Egyetem & & & & & & \\
\hline & Elemi & & & & $\begin{array}{c}- \\
594.543 \\
\end{array}$ & 68.775 & .000 \\
\hline & Általános & & & & $\begin{array}{c}- \\
553.973 \\
\end{array}$ & 45.655 & .000 \\
\hline & Szakiskola & & & & $\begin{array}{c}- \\
427.486\end{array}$ & 41.952 & .000 \\
\hline & Érettségi & & & & $\begin{array}{c}- \\
301.294\end{array}$ & 37.292 & .000 \\
\hline \multirow{7}{*}{$\begin{array}{l}\text { Gazdasági } \\
\text { aktivitás }\end{array}$} & Alkalmazott & & & & & & \\
\hline & $\begin{array}{l}\text { Önfoglalkoztató, } \\
\text { vállalkozó }\end{array}$ & & & & 70.081 & 47.682 & .142 \\
\hline & Nyugdíjas & & & & -40.500 & 40.840 & .322 \\
\hline & Háztartásbeli & & & & $\begin{array}{c}- \\
157.137 \\
\end{array}$ & 53.536 & .003 \\
\hline & $\begin{array}{l}\text { Diák vagy } \\
\text { egyetemi } \\
\text { hallgató }\end{array}$ & & & & $\begin{array}{c}- \\
139.114\end{array}$ & 63.827 & .030 \\
\hline & munkanélküli & & & & $\begin{array}{c}- \\
303.007 \\
\end{array}$ & 46.974 & .000 \\
\hline & Egyéb inaktív & & & & $\begin{array}{c}- \\
235.381 \\
\end{array}$ & 67.669 & .001 \\
\hline \multirow{4}{*}{$\begin{array}{l}\text { A település } \\
\text { lakosságszáma }\end{array}$} & 2000 fó alatt & & & & & & \\
\hline & $2-10.000$ & & & & 36.497 & 33.145 & .271 \\
\hline & $10-100.000$ & & & & 90.827 & 40.819 & .026 \\
\hline & 100.000 fö felett & & & & 184.888 & 47.893 & .000 \\
\hline \multirow[t]{3}{*}{ régió } & Székelyföld & & & & & & \\
\hline & Partium & & & & -60.427 & 39.659 & .128 \\
\hline & Közép-Erdély & & & & 53.645 & 58.000 & .355 \\
\hline
\end{tabular}

REGIO 27. évf. (2019) 1. szám 37-80. 


\begin{tabular}{|c|c|c|c|c|c|c|c|}
\hline \multirow{3}{*}{ Változó } & \multirow{2}{*}{ Változóértékek } & \multicolumn{3}{|c|}{ Egyszerü modell } & \multicolumn{3}{|c|}{ Bővített modell } \\
\hline & & B & std. h. & szign. & B & std. h. & szign. \\
\hline & $\begin{array}{l}\text { Észak- és Dél- } \\
\text { Erdély }\end{array}$ & & & & 46.828 & 53.624 & .383 \\
\hline \multirow{5}{*}{$\begin{array}{l}\text { A magyarok } \\
\text { százalékos } \\
\text { aránya a } \\
\text { községben, } \\
\text { városban }\end{array}$} & $90 \%$ felett & & & & & & \\
\hline & $60-89.9 \%$ & & & & 95.731 & 34.362 & .005 \\
\hline & $40-59.9 \%$ & & & & -8.845 & 83.278 & .915 \\
\hline & $20-39.9 \%$ & & & & 57.324 & 53.275 & .282 \\
\hline & $20 \%$ alatt & & & & 113.417 & 67.214 & .092 \\
\hline
\end{tabular}

Forrás: CCCDC-RIRNM 2012 vizsgálat

Az alapmodell eredményei azt mutatják, hogy a jövedelem szempontjából a magyar családon kívüli kapcsolatoknak van egyedül jelentősége: minél több távolabbi rokoni, baráti, ismerősi kapcsolatot tud valaki mobilizálni a felsorolt élethelyzetekben, annál magasabb a családjában az egy före jutó ekvivalens jövedelem. A románokkal való intenzívebb kapcsolattartás nem befolyásolja a jövedelmeket, az etnikai csoporton kívüli kötések, a bridging tőkeként címkézett erőforrás gazdaságilag tehát nem hasznosul. Arra is számítottunk, hogy eltérő etnikai összetételü környezetben ez a hatás eltérően érvényesül - például a szórványvidékeken, ahol a magyarok jelentős kisebbségben vannak, a románokkal müködtetett kapcsolatok fontosabbak lesznek az anyagi érvényesülésben. Alapmodellünket ezért a magyarok százalékos aránya szerinti öt kategóriában különkülön lefuttattuk, de jelentős különbséget ebben a tekintetben nem észleltünk (8. táblázat). Egyedül a színmagyar településeken számítanak a családon belüli román kapcsolatok, de itt a hatásuk éppen fordított. Paritásos nemzetiségi megoszlás mellett a magyar kapcsolatok kiterjedtsége felértékelődik, lényegesen többet magyaráz a jövedelmek eltéréseiből ott, ahol a magyarok aránya 20 és 60 százalék között van.

REGIO 27. évf. (2019) 1. szám 37-80. 
8. Táblázat A háztartások egy főre jutó ekvivalens jövedelmének meghatározói (nemek és magyarok településenkénti aránya szerint elkülönített kategóriákban) - 2012 - standardizált lineáris regressziós együtthatók

\begin{tabular}{|c|c|c|c|c|c|c|c|c|}
\hline & & \multicolumn{2}{|c|}{ nemek } & \multicolumn{5}{|c|}{$\begin{array}{c}\text { magyarok aránya a községben/városban } \\
(\%)\end{array}$} \\
\hline & & férfi & nö & $0-19,9$ & $20-39,9$ & $\begin{array}{c}40- \\
59,9 \\
\end{array}$ & $60-89,9$ & $\begin{array}{l}90- \\
100\end{array}$ \\
\hline \multirow[t]{4}{*}{$\begin{array}{l}\text { Strukturális } \\
\text { társadalmi } \\
\text { tőke }\end{array}$} & $\begin{array}{l}\text { családon } \\
\text { belüli } \\
\text { magyar } \\
\text { kapcsolatok }\end{array}$ & -.022 & -.053 & -.045 & -.038 & .038 & -.049 & -.015 \\
\hline & $\begin{array}{l}\text { családon } \\
\text { kívüli } \\
\text { magyar } \\
\text { kapcsolatok }\end{array}$ & $.161 * * *$ & $.174 * * *$ & $.158 * * *$ & $.341 * * *$ & $.265^{*}$ & $.203 * * *$ & .069 \\
\hline & $\begin{array}{l}\text { családon } \\
\text { belüli román } \\
\text { kapcsolatok }\end{array}$ & .014 & .000 & .024 & .067 & -.095 & .084 &.- \\
\hline & $\begin{array}{l}\text { családon } \\
\text { kívüli román } \\
\text { kapcsolatok }\end{array}$ & .060 & .030 & -.069 & -.032 & .229 & -.064 & .074 \\
\hline \multirow{3}{*}{$\begin{array}{l}\text { Kognitív } \\
\text { társadalmi } \\
\text { tőke }\end{array}$} & $\begin{array}{l}\text { általánosított } \\
\text { bizalom }\end{array}$ & .064 & -.011 & -.097 & .117 & $.269^{*}$ & .091 & .000 \\
\hline & $\begin{array}{l}\text { bizalom a } \\
\text { magyarokban }\end{array}$ & .056 & .034 & $.175^{*}$ & -.009 & $\begin{array}{r}- \\
.398 * * \\
\end{array}$ & -.050 & .052 \\
\hline & $\begin{array}{l}\text { bizalom a } \\
\text { románokban }\end{array}$ & -.006 & $.099 *$ & .060 & .151 & $.417 * *$ & -.001 & .082 \\
\hline \multicolumn{2}{|l|}{ R négyzet } & 0.029 & 0.033 & 0.083 & 0.153 & 0.274 & 0.066 & 0.033 \\
\hline
\end{tabular}

$* 0.05>\mathrm{p}>0.01$. ***0.01>p $>0.001$. *** $\mathrm{p}<0.001$. Forrás: CCCDCRIRNM 2012 vizsgálat

$\mathrm{Az}$ alapmodellben a társadalmi tőke kognitív összetevője, a bizalom, változó hatással van a jövedelmekre annak függvényében, hogy egy településen mekkora a magyarok aránya. Erős etnikai polarizáció mellett a magas generalizált bizalom növelheti a jövedelmi esélyeket, csakúgy, mint a románokkal szembeni bizalom. Ezeken a településeken erösebb a verseny a társadalmi pozíciókért az

REGIO 27. évf. (2019) 1. szám 37-80. 
etnikai csoportok között, és azoknak a magyaroknak nagyobb a jutalma, akik felszabadultabban mozognak ebben az interetnikus térben. A bővített modell szerint a kevésbé polarizált etnikai környezetben valószínüleg ennek az ellenkezője igaz: éppen a magyarokkal szembeni nagyobb bizalom jár jövedelmi előnyökkel.

Hasonló eredményeket hozott a jövedelmi szegénység meghatározóival kapcsolatos modellünk is, itt ugyanúgy a magyar „gyenge kötések” szerepe a fontosabb (9. táblázat). Azoknál kisebb a szegénység kockázata, akiknek kiterjedtebb a különböző élethelyzetekben a családon kívül mobilizálható magyar kapcsolathálózatuk. Nagy a valószínüsége annak is, hogy az alacsony általánosított bizalom is összefügg a szegénységgel, ennek a kauzalitása viszont jó eséllyel fordított. Ráadásul mivel nagyon kevesen vannak a mintában olyanok, akik bíznak az emberekben $(8,1$ százalék), ez a kapcsolat nem is szignifikáns.

9. Táblázat. A jövedelmi szegénység kockázatának a determinánsai (logisztikus regresszió) - 2012

\begin{tabular}{|l|l|c|c|c|c|c|}
\hline \multicolumn{1}{|c|}{ Változó } & Változóértékek & B & Std.h. & Wald & szign. & Exp(B) \\
\hline Konstans & -1.149 & 0.190 & 36.445 & 0.000 & 0.317 \\
\hline $\begin{array}{l}\text { Strukturális } \\
\text { társadalmi } \\
\text { tőke }\end{array}$ & $\begin{array}{l}\text { családon belüli } \\
\text { magyar } \\
\text { kapcsolatok }\end{array}$ & 0.002 & 0.051 & 0.001 & 0.972 & 1.002 \\
\cline { 2 - 7 } & $\begin{array}{l}\text { családon kívüli } \\
\text { magyar } \\
\text { kapcsolatok }\end{array}$ & -0.161 & 0.039 & 16.97 & 0.000 & 0.851 \\
\cline { 2 - 7 } & $\begin{array}{l}\text { családon belüli } \\
\text { román } \\
\text { kapcsolatok }\end{array}$ & 0.064 & 0.213 & 0.089 & 0.765 & 1.066 \\
\cline { 2 - 7 } & $\begin{array}{l}\text { családon kívüli } \\
\text { román } \\
\text { kapcsolatok }\end{array}$ & -0.101 & 0.097 & 1.087 & 0.297 & 0.904 \\
\hline $\begin{array}{l}\text { Kognitív } \\
\text { társadalmi } \\
\text { tőke }\end{array}$ & $\begin{array}{l}\text { általánosított } \\
\text { bizalom }\end{array}$ & -0.602 & 0.349 & 2.977 & 0.084 & 0.548 \\
\cline { 2 - 7 } & $\begin{array}{l}\text { bizalom a } \\
\text { magyarokban }\end{array}$ & -0.081 & 0.178 & 0.208 & 0.649 & 0.922 \\
\cline { 2 - 7 } & $\begin{array}{l}\text { bizalom a } \\
\text { románokban }\end{array}$ & 0.102 & 0.219 & 0.218 & 0.641 & 1.108 \\
\hline
\end{tabular}

$\mathrm{R}^{2}($ Nagelkerke) $=0,036$. Forrás: CCCDC-RIRNM 2012 vizsgálat

REGIO 27. évf. (2019) 1. szám 37-80. 
A társadalmi töke és a jövedelmek viszonyáról - az említett kivételekkel - ezek az adatok azt sugallják, hogy az erdélyi magyarok esetében mind a strukturális, mind pedig a kognitív dimenzióban általában az etnikai homofília a kifizetődőbb. A saját etnikumon belüli, bonding típusú gyenge kötések, kognitív vonalon pedig a magyarokkal szembeni magasabb bizalom jár nagyon enyhe, de szignifikáns jövedelmi előnyökkel. Ugyanakkor azt is valószínűsítik, hogy a románokkal kialakított hídkapcsolatok általában nem váltják be a hozzájuk füzött reményeket, nem segítik elő a jobb boldogulást (,get ahead") a munkaerőpiacon. Modelljeink magyarázóereje azonban gyenge, és a következtetés szembemegy a szakirodalom főnarratívájával, éppen ezért további ellenőrzésre és árnyaltabb vizsgálatra szorul. Megállapításaink tehát mindaddig hipotézisértékűek maradnak, amíg további kutatások nem igazolják. ${ }^{50}$

${ }^{50} \mathrm{Az}$ említett kutatások érvényességén és megbízhatóságán egyaránt lenne javítanivaló. Érvényességi szempontból, a „súlyosságuk” sorrendjében az alábbi problémák merültek fel: 1. A CCCDC-RIRNM 2012 vizsgálatban az egyéni jellemzők és teljesítmény alapján magyarázzuk az egy főre jutó ekvivalens jövedelmet, pedig az az összes családtag jellemzőinek és teljesítményének az eredője. A kérdőívben sajnos az egyéni jövedelmet nem mérték. 2. Még pontosabban és árnyaltabban kellene operacionalizálni és mérni a társadalmi tőke különböző dimenzióit. 3. Regressziós modelljeinkben nem sikerült kiküszöbölni sem a fordított kauzalitás, sem az endogenitás problémáját. (pl. a bizalom és a jövedelmek között). Megbízhatósági szempontból: 1. Kisebbségi mintán mindig felmerül a probléma, hogy szórványban az erősebb etnikai kötődésű, etnikailag jobban beágyazott alanyok láthatóbbak, ezért könnyebb őket elérni. Valószínűsíthető, hogy minden, a véletlenszerüség elvét szigorúan betartató szabály ellenére a szórványban felülreprezentáltak a kevésbé asszimilálódott magyarok, 2. Nagyobb elemszámú mintákra lett volna szükség ahhoz, hogy az említett hatásokat a társadalom különböző rétegein pontosabban megvizsgáljuk. Szinte bizonyos, hogy az etnikailag heterogén kapcsolatok jelentősége különböző foglalkozáskategóriákban eltérő. 3. Az elemzés során nem foglalkoztunk a kapcsolatok redundanciájával az említett 5 interakciós helyzetben - ez némileg változtathat a kapcsolatok aggregált (etnikai) heterogenitásán is.

REGIO 27. évf. (2019) 1. szám 37-80. 


\section{A bonding társadalmi töke tárgyiasulása - a gazdasági etnocentrizmus és az etnikai vállalkozások}

Az említettek alapján két okból is érdemes az összekötő (bonding) tőkével folytatni a vizsgálódást. Bár a változásokat nem sikerült tetten érni, továbbra is logikus az a feltételezés, hogy a magyarok földrajzi koncentrálódásával növekedni fog a szerepe, kevesebb magyarnak lesz kapcsolata a többségi etnikum tagjaival, illetve egyre kevesebb lesz a „mozgósítható” román nexus. ${ }^{51}$ Másrészről láthattuk, hogy bővülése - a magyar ,gyenge kötések” gyarapodása - jövedelmi előnyökkel járhat.

A társadalmi tőkefajták kapcsán mindeddig egyéni terminusokban beszéltünk. Az összekötő társadalmi tőke azonban, például a kérdöívekben mért kölcsönös segítségnyújtás mentén, erősítheti az etnikai csoporton belüli társadalmi szolidaritást és bizalmat. Ahol bizalom van, ott pedig alacsonyabbak a tranzakciós költségek, kevesebbet kell költeni a gazdasági interakciók felügyeletére, szerződések kikényszerítésére $s t b .{ }^{52}$, ezeket az összegeket fejlesztésre, beruházásra vagy akár jóléti célokra lehet fordítani. Magasabb bizalom és szolidaritás mellett ugyanakkor alacsonyabb a korrupció és a járadékvadászat, hatékonyabb a közjavakkal való gazdálkodás is. A társadalmi tőke tehát kollektív erőforrásjelleget kap.

Az etnikai csoporton belüli „korlátozott szolidaritásnak” és „kikényszeríthető bizalomnak" 53 azonban nemcsak oka, hanem egyben következménye is a csoporton belüli nagyobb interakciósürüség. Ez azt is jelenti, hogy az azonos etnikumúak hajlamosak az ügyeiket egymással intézni, beleértve a gazdaságiakat is - egymástól kérnek segítséget, egymással kötnek üzletet, egymással dolgoznak, egymástól vásárolnak. A szolidaritás az együttmüködés normatív dimenziója, a közös értékelkötelezettség, kollektív identitásreprezentációk mentén aktiválódik. A bizalom inkább

51 Ezt ellensúlyozhatja az interneten keresztüli kapcsolattartás, illetve az ideiglenes földrajzi mobilitás lehetősége - például autópályán egyszerübb lenne az ingázás a régiók között, ezzel együtt egy intenzívebb kapcsolatápolás a különböző etnikumok között.

52 Orbán - Szántó, 2005.

${ }^{53}$ Portes, 1998.

REGIO 27. évf. (2019) 1. szám 37-80. 
kognitív síkon segíti elő az együttmüködést - garanciákat tartalmaz arra nézvést, hogy az együttmüködés a megegyezett feltételek szerint megy végbe.

\subsection{Gazdasági etnocentrizmus}

A kollektív bonding típusú társadalmi tőke egyik látható, megfogható megnyilvánulási formája a gazdasági etnocentrizmus. Ide tartozónak sorolunk minden olyan gazdasági (fogyasztói) diszpozíciót és döntést ${ }^{54}$, amelyek az (erdélyi) magyar termékek vagy szolgáltatások preferálásában nyilvánulnak meg - függetlenül attól, hogy emögött a haszonmaximalizáló racionalitás, vagy morális szempontok vannak.

Az erdélyi magyarok gazdasági etnocentrizmusát az elmúlt években több kutatásban is mértük $\mathrm{k}^{55}$. Az operacionalizálási próbálkozások közül a legösszetettebb egy 2008-ben készült kérdéssor, ${ }^{56}$ amely hat hipotetikus helyzetben kérdez rá az alanyokra, hogy mennyire tartják fontosnak, hogy azonos etnikumú partnerrel bonyolítsanak le valamilyen gazdasági tranzakciót. Ebből a hat változóból egy aggregált mutató készült, ${ }^{57}$ aminek az átlagait és a szórását az alábbi táblázat mutatja:

\footnotetext{
${ }^{54}$ Shimp, Terence A.: Consumer ethnocentrism: The concept and a preliminary empirical test. Advances in Consumer Research Volume 11, 1984.

${ }^{55}$ Csata Zsombor - Deák Attila. Gazdasági etnocentrizmus, etnikai fogyasztás az erdélyi magyarok körében. Közgazdász Fórum, Volume 13, issue. 95, 2010. 3148.; Csata Zsombor: A fogyasztói magatartás etnikai vonatkozásai a kolozsvári magyar egyetemi hallgatók körében - Kutatásjelentés. Kolozsvár: BBTE Magyar Szociológia és Szociális Munkásképző Kar, 2014.

$56 \mathrm{Az}$ idézett kutatás a „Társadalmi szolidaritás és etnikumközi viszonyok Romániában" c. országos kérdőíves vizsgálat, melynek felvételére 2008 októbernovemberében került sor a kolozsvári székhelyü Nemzeti Kisebbségkutató Intézet, valamint az Erdélyi Etnikumközi Viszonyok Kutatóközpontja koordinálásában. A teljes minta 1723 esetet tartalmaz (ebböl 607 magyar nemzetiségü), és területi eloszlás, nemek és korcsoportok szerint reprezentatív.

${ }^{57}$ A változók az alábbiak voltak: 1. „Hajlandó-e többet fizetni a termékért, ha azt Romániában/Magyarországon gyártották?”, 2. „Képzelje el, hogy vásárláskor egy román, egy magyar és egy roma eladó közül választhat. A kínálat, minőség és ár tekintetében nincs különbség. Ön inkább melyiküktől vásárolna?”, 3. „Képzelje el, hogy lehetősége lenne rá, hogy plusz jövedelem fejében bérbe adja lakását! Ha választania kellene, inkább kinek adná ki?”, 4. „Hajlandó lenne a lakbér bizonyos hányadáról lemondani annak fejében, hogy magyar bérlöje legyen?”, 5. „Ha el
} 
10. táblázat. A gazdasági etnocentrizmus mutató átlagértéke és szórása, etnikai bontásban (egy 0-tól 6-ig terjedő skálán, $\mathrm{N}=587$ )

\begin{tabular}{|l|c|c|}
\hline & átlag & szórás \\
\hline székelyföldi magyarok & 2,68 & 1,76 \\
\hline magyarok & 2,27 & 1,69 \\
\hline erdélyi románok & 1,53 & 1,33 \\
\hline románok & 1,84 & 1,41 \\
\hline székelyföldi magyarok & 2,68 & 1,76 \\
\hline
\end{tabular}

Forrás: Etnobarométer 2008 vizsgálat

Az etnikai bontásban vizsgált eredmények azt mutatják, hogy a romániai magyar kisebbség gazdasági etnocentrizmusa mindegyik hipotetikus tranzakciós helyzetben nagyobb mértékü, mint a románoké. Az összevont mutatóban a 0-tól 6-ig terjedő skálán az erdélyi románok 1,53-as, az erdélyi magyarok 2,27-es átlagot értek el, a különbségek természetesen szignifikánsak. A különbség azt jelzi, hogy az erdélyi magyarok gazdasági etnocentrizmusa nem pusztán nacionalista attitüdök általános, reflektálatlan lenyomata, hanem a kisebbségi státus valamiféle kollektív, tudatos megélésével is összefüggésben van, a bonding típusú tőkeként definiált társadalmi erőforrás egyik megnyilvánulásáról van szó.

Ezt igazolja a regressziós modellünk is (11. táblázat), amely szerint az erdélyi magyarok gazdasági etnocentrizmusáért leginkább a románokkal szembeni bizalmatlanság a felelős, de a többségi nemzettel való kapcsolattartás hiánya vagy alacsony intenzitása is etnocentrikusabb piaci magatartást valószínüsít. Valamivel gyengébb, de szintén pozitív parciális hatása van a székelyföldi lakhelynek, ehhez képest a szórványhelyzetben élők etnikai érzékenysége szignifikánsan alacsonyabb.

kéne adjon egy, a tulajdonában lévő telket, milyen mértékben lenne hajlandó eladni azt egy románnak/magyarnak?” 6. Egyetértés azzal, hogy „Természetes, hogy egy magyar alkalmazó előnyben részesítsen egy magyar személyt, egy román ellenében, mert jobban megbízhat benne." Az új változó így 0-től 6-ig vehet fel értékeket, a magasabb pontszám magasabb fokú gazdasági etnocentrizmust jelent.

REGIO 27. évf. (2019) 1. szám 37-80. 
11. táblázat: A gazdasági etnocentrizmus meghatározóinak lineáris regressziós modellje $(2008, \mathrm{~N}=587)$

\begin{tabular}{|l|c|c|c|}
\hline & $\begin{array}{c}\text { Standardizálatlan } \\
\text { regressziós } \\
\text { együttható }\end{array}$ & $\begin{array}{c}\text { Standard } \\
\text { hiba }\end{array}$ & $\begin{array}{c}\text { Standardizált } \\
\text { regressziós } \\
\text { együttható }\end{array}$ \\
\hline Konstans & 2.885 & 0.207 & \\
\hline Székelyföldi lakhely & $0.301^{*}$ & 0.145 & 0.098 \\
\hline Magyar többség a településen & -0.097 & 0.179 & -0.023 \\
\hline Fele-fele arányú megoszlás & -0.235 & 0.189 & -0.057 \\
\hline $\begin{array}{l}\text { Magyarok kisebbségben a } \\
\text { településen }\end{array}$ & $-0.462^{* *}$ & 0.184 & -0.129 \\
\hline $\begin{array}{l}\text { Magyarok szórványban a } \\
\text { településes (10 százalék alatt) }\end{array}$ & 0.002 & 0.251 & 0.001 \\
\hline Vegyesházasság a családban & -0.337 & 0.252 & -0.055 \\
\hline $\begin{array}{l}\text { Románokkal való } \\
\text { kapcsolattartás intenzitása } \\
\text { (sürüsége) }\end{array}$ & $-0.083^{* * *}$ & 0.025 & -0.140 \\
\hline Általános bizalom & & & \\
\hline Bizalom a románokban & $-0.665^{* * *}$ & 0.141 & -0.189 \\
\hline $\begin{array}{l}\text { Determinációs együttható }(\mathrm{R} \\
\text { négyzet) }\end{array}$ & \multicolumn{3}{|l}{0.125} \\
\hline
\end{tabular}

Jelmagyarázat: * $0,05>\mathrm{p}>0,01, * * 0,01>\mathrm{p}>0,001, * * * \mathrm{p}<0,001$

Forrás: Etnobarométer 2008 vizsgálat

Bár változatos tranzakciós szituációkra és cselekvési projekciókra vonatkoznak, a gazdasági etnocentrizmusra vonatkozó becsléseink csak diszpozíciókat jelölnek. Sajnos keveset tudunk arról, hogy valós élethelyzetekben a vásárlók ténylegesen hogyan döntenek, választásaikban mennyire játszik aktív szerepet az etnocentrizmus, ezzel kapcsolatos kutatások még nem készültek Erdélyben. Adataink csak azt támasszák alá, hogy létezik az etnikai szolidaritás mentén artikulálódó kooperációs igény az erdélyi magyarok körében, amire etnikai piacot lehet építeni, és hogy az említett változók mentén viszonylag jól behatárolható az a célcsoport, akik érzékenyebbek lehetnek a sajátosan etnikai referenciájú, magyar nyelven közvetített üzenetekre.

REGIO 27. évf. (2019) 1. szám 37-80. 


\subsection{Etnikai vállalkozások}

Az etnikai alapú összekötő társadalmi tőke gazdasági objektiválódása inkább az etnikai vállalkozások elterjedésében érhető tetten. Erdélyben az utóbbi években egyre több olyan üzleti célú kezdeményezés jelenik meg, amely tudatosan magyar fogyasztókat szeretne meghódítani magának, a magyarok etnikai szolidaritására apellálva piaci versenyelönyre próbál szert tenni. Látható jelei vannak annak is, hogy a nagyobb cégek a marketingstratégiájukban az erdélyi vagy a székelyföldi magyar vásárlókat egy külön fogyasztói szegmensként kezelik.

Ennek a piaci szegmensnek az egyik legnagyobb szereplője a Merkúr áruházlánc, melyet egy korábbi helyi kisboltláncot átalakítva hoztak létre, elöször Székelyudvarhelyen. Az üzletlánc jelenleg öt székelyföldi városban 12 üzletet müködtet és a multinacionális kereskedők (Lidl, Kaufland stb.) sikeres versenytársaiként van jelen. A cégnek jelenleg több mint 500 alkalmazottja van, és 2017-ben 41 millió euró feletti forgalmat bonyolított le.

Ennek egy jelentős része az általa forgalmazott Góbé termékekből származik, amelyet egy sajátos marketingkoncepció mentén egyfajta márkatermékként értékesítenek. A Góbé 64 székelyföldi termelő több mint 350 termékét fogja össze, amelyek azonos arculattal jelennek meg saját üzleteikben és a viszonteladóknál egyaránt. A Góbé ugyan kereskedelmi márkaként viselkedik, de mivel egyedi helyi termelők termékeit promoválja és forgalmazza, leginkább közösségi márkaként lehet rá tekinteni.

A Merkúr székelyföldi üzletláncként reklámozza magát, és mivel minden termékük kizárólag székelyföldi, a logó, az arculati elemek is mind Székelyföldre utalnak (hagyományos székely falukép alapján kitalált, stilizált elemek). Bár a menedzsment regionális brandként definiálja a Góbét, ahová bármelyik székelyföldi termelő bekapcsolódhat, a beszállítóik egyelöre kizárólag magyarok. Ezek alapján nem véletlen tehát, hogy a vevők számára a termékek egy etnikai alapú hozzáadott értéket is hordoznak. Erre az identitásra csak ráerősít az, hogy a Merkúrban nagy mennyiségben forgalmaznak magyarországi termékeket is.

$\mathrm{Az}$ etnoregionális szolidaritás még látványosabb kommodifikációja zajlik egy nemrégiben piacra vitt székely termék, az Igazi Csíki Sör esetében is. Ezt a márkát - jelentős magyarországi

REGIO 27. évf. (2019) 1. szám 37-80. 
hátszéllel - 2014-ben hozták létre, és a termékimázs kialakításánál kizárólag a székelyek történelméböl, néprajzi és kulturális hagyatékából inspirált szimbólumokat és narratívákat használtak, üzeneteiket kizárólag magyarul fogalmazták meg. Az erre épített marketingmodell kezdetben sikeres volt, a sörmanufaktúra akkor került a figyelem középpontjába, amikor a holland multinacionális vállalat, a Heineken Romania beperelte a céget az Igazi Csíki Sör márkanév használata miatt. Ök ugyanis korábban már levédték a név - szerintük hasonló - román fordítását, a Ciuc Premium-ot, melyet szintén a Székelyföldön, Csíkszeredában palackoznak. Az Igazi Csíki Sörnek úgy tünik kapóra jött a jogvita, ugyanis lehetővé tette, hogy a fogyasztók egyfajta Dávid-Góliát harcot lássanak a kis székelyföldi sörmanufaktúra és a helyi termelőt ellehetetlenítő, szívtelen, profitorientált multicég között. A kampánynak köszönhetően a helyiek bojkottálni kezdték a Székelyföld létezését egyik nyilatkozatában megkérdőjelező Heineken termékeit. A nyilvános vitába beszállt a magyar kormány is, és azzal fenyegetőzött, hogy válaszként megtiltja a Heinekennek a piros csillagnak, mint totalitárius szimbólumnak a használatát. A márkanév körüli jogvita végül kiegyezéssel véget ért, és Tiltott Csíki Sör-ként továbbra is népszerü a székelyföldi magyar fogyasztók körében, magyarországi terjeszkedése viszont nem volt sikeres, és 2016-17-ben már jelentős veszteséget halmozott fel.

$\mathrm{Az}$ említett példák jól szemléltetik, hogy a régió magyar népességének korlátozott szolidaritására és kikényszeríthető bizalmára épülő üzleti modell sikeres lehet a Székelyföldön. Ehhez az is hozzájárul, hogy az egyes termékkoncepciók az etnikai markerek mellett más fogyasztásetikai elemeket is sikeresen integrálnak (regionalizmus, globalizációellenesség, környezettudatosság, biokultúra stb.) A jelenség joggal tekinthető tehát az etikai fogyasztás egyfajta kollektív megnyilvánulásának is ${ }^{58}$.

Antropológiai szempontból érdekes az a további kérdés is, hogy az életképes magyar vállalkozások, brandek, termékek és gazdasági kooperációs gyakorlatok mennyiben járulnak hozzá az etnikairegionális identitás további megerősítéséhez, vagy éppen ellenkezőleg: elindítják, gyorsítják az említett kulturális markerek

\footnotetext{
${ }^{58}$ Lewis, Tania - Potter, Emily: Ethical consumption: A critical introduction. Routledge, 2013.
}

REGIO 27. évf. (2019) 1. szám 37-80. 
erózióját. Az eddigiek alapján csupán annyit mondhatunk, hogy az EU-s piaci dereguláció talaján a fogyasztói ösztönzés klasszikus eszközeit használva spontán módon hozzájárulnak a kétnyelvüség fejlődéséhez és a hivatalos román nyelvi hegemónia csökkentéséhez a régióban.

\section{6. Összegzés és kitekintés}

A gazdaságfejlesztési stratégiák készítői, a szakértők és a politikusok is egyetértenek abban, hogy a magyarok társadalmi pozícióinak a javításához az oktatáson és a gazdasági intézmények fejlesztésén keresztül vezet az út. A magyar nyelvü oktatási rendszer jelentős mértékben a kisebbségi vezetők és döntéshozók felügyelete alatt áll, irányítását, szervezését, minőségét - a folyamatos finanszírozási problémák ellenére - érdemben befolyásolni tudják. A gazdaságot ezzel szemben elsősorban a piac spontán folyamatai irányítják, intézményi környezetének a kialakításában az etnicitás szerepe kevésbé jelentős. Messze nem beszélhetünk olyan intézményi párhuzamosságokról a gazdaság területén, mint amilyenek az oktatásban, a kultúrában vagy az egyházban vannak jelen ${ }^{59}$. A tanulmányban bemutatott megfigyelések és empirikus adatok alapján kijelenthető azonban, hogy az etnicitás szerepe növekvőben van a gazdasági folyamatok, interakciók vezérlésében és ez összefügg azzal, hogy növekszik a magyarok földrajzi koncentrációja Erdélyben.

A bevezetőben - neoinstitucionalista logikában - abból indultunk ki, hogy az etnicitás szerepe a gazdasági folyamatok koordinációjában azon múlik, hogy 1. milyen a regulációs környezet, mennyire jól müködnek a gazdasági együttmüködés zavartalanságát, a szabad versenyt garantáló intézmények, mekkora a bizalom ezekben az intézményekben és általában a gazdasági szereplőkben; 2. mekkorák a pozícionális és kulturális különbségek az egyes etnikumok között, amelyek meghatározhatják a preferenciáik különbözőségét. Alacsony bizalom és magas divergencia mellett az etnicitás jelentősége felerősödik a gazdaságban.

Arról, hogy Romániában mennyire müködnek demokratikusan és hatékonyan a reguláció intézményei, csak relatív értelemben

${ }^{59}$ Kiss, 2015.

REGIO 27. évf. (2019) 1. szám 37-80. 
beszélhetünk. Konszenzus van viszont arról ${ }^{60}$ - és ebben a tanulmányban is láthattuk -, hogy az intézményekbe vetett bizalom, az általánosított bizalom és az etnikumok közötti bizalom egyaránt alacsony. Több empirikus felvétel is igazolja, hogy a románok és a magyarok között a pozícionális különbségek növekednek, erösödnek a jövedelmi különbségek, az etnicitás mentén nőnek a társadalmi egyenlötlenségek ${ }^{61}$. A kulturális különbözőségek mértéke szintén csak viszonyítási standardok mentén állapítható meg, a nyelvek közötti távolság azonban egy olyan objektív tény, amin nem lehet változtatni. Határozott véleményünk az, hogy a nyelvi különbségek gazdasági szerepével nem foglalkozott eleget a szakirodalom és alábecsülte a jelentőségét ${ }^{62}$, ezért nagyon fontos, hogy ezen a területen további elemzések készüljenek. Nagyon fontos fejlemény

${ }^{60}$ Csata Zsombor: Confiance ou scepticisme: l'evaluation des institutions civiles et politiques en Roumanie. In: Sossa, Dorothé (ed.): Nouvelles democraties et socialisation politique. Etude comparee des cas du Benin, du Bukina Faso et de la Roumanie. Paris: L’Harmattan, 2011. 181-204.

61 Csata Zsombor: Munkaeröpiaci egyenlötlenségek Romániában, etnikai metszetben. Erdélyi Tásadalom, 2017. 15(1). 81-104.

${ }^{62}$ L. pl. Brubaker et al. 2006, akik a kolozsvári interetnikus viszonyokról szóló könyvükben ugyan egy teljes fejezetet szentelnek a nyelvhasználatnak, a gazdasági vonatkozásokra legfeljebb utalásokat tesznek, azokat nem gondolják módszeresen végig. Itt-ott felbukkan ugyan, hogy a román nyelvtanulás, nyelvhasználat „erőfeszítés” a magyarok számára, a nyelvváltás „diszkomfortérzetet” okozhat, de ezek nem részei a főnarratívának. Nehezen is lehetnének, hiszen ha elismerik 1 . az etnicitás és a nyelv eröteljes összefonódását Erdélyben, és 2. hogy a román nyelv ismerete a magyarok számára nem adott (mint a levegővétel), hanem erőfeszítést, befektetést, ráfordítást igényel, jelentős haszonáldozat-költséggel jár, tehát tagadhatatlanul egy objektíve megragadható, kitapintható és pontosan mérhető erőforrás, akkor újra kellene gondolni az etnicitás társadalmilag megkonstruált voltáról szóló tézisük érvényességét Erdélyben. De akár tekinthetjük az etnicitást társadalmi felépítménynek, ki is dobhatjuk ezt a fogalmat az elemzésekből (mint ahogy azt a nyelvközgazdászok teszik Quebec vagy Svájc esetében), de attól még a nyelvi különbségek és a vele járó aszimmetriák megmaradnak, nem lesz egyenlőbb a társadalom, a lényeg tehát nem változik. Az etnicitás erőforrásjellegéről vitatkozhatunk, a nyelvtudáséról viszont nem. Az etnikai határok lehetnek képlékenyek, a nyelviek viszont nem azok. A nyelvgazdasági érvekröl bővebben 1. Grin, Francois: Langue et différentiels de statut socio-économique en Suisse. Berne: Office Fédéral de la Statistique. 1997.; Vaillancourt, Francois: Language and Socioeconomic Status in Quebec: Measurement, Findings, Determinants, and Policy Costs. International Journal of the Sociology of Language, 1996. 121(1). 69-92.

REGIO 27. évf. (2019) 1. szám 37-80. 
például, hogy romlik a magyarok román nyelvtudása, és ezt bünteti a piac. A román nyelv elsajátítása pedig egyre nagyobb erőfeszítést igényel, ${ }^{63}$ mert: 1 . az intézményes oktatás hatékonysága nagyon alacsony, és bár történtek pozitív változások, a korszerüsítéssel állandó lemaradásban van; 2. a műholdas televíziózással és az internet elterjedésével csökken a román médiakitettség; 3. a magyar népesség tömbösödésével és az etnikailag integrált intézmények számának növekedésével ${ }^{64}$ egyre kisebb lesz a személyes, face-to-face románmagyar interakciók sürüsége; 4. ennek aggregált hatásaként csökken a motiváció is a román nyelv megtanulására. És ezt láthatóan nem képes ellensúlyozni az a fenyegetettség, hogy a magyarok rosszabb állásokban és gyengébb fizetésért lesznek kénytelenek dolgozni a romániai munkaerőpiacon. A nyelvi hátrányból fakadó jövedelemkülönbségek megszüntetésének ésszerü és egyedüli méltányos megoldása lehetne a szimmetrikus kétnyelvüség - a területi alapon koercív nyelvi rezsim ${ }^{65}$ - bevezetése azokon a területeken, ahol a magyarok relatív többségben vannak. Erről a román politikum azonban hallani sem akar, tehát az esélyei minimálisak ${ }^{66}$.

Ebben a tekintetben egy további fontos fejlemény, hogy az EU-s csatlakozással a magyarországi és az európai piacok elérhetősége

\footnotetext{
${ }^{63}$ A reciprok kétnyelvüség hasonlóan, de annak az esélyei minimálisak, ezzel kapcsolatban 1. Csata 2016.

${ }^{64}$ Itt elsősorban az oktatás, a kultúra, az egyház és részben a helyi adminisztráció intézményeire gondolunk, de nemcsak: az erdélyi nagyvárosokban például a magángazdaság (elsősorban ingatlanépítések) terjeszkedésével egyre inkább beszükülnek az ingyen használható közterek. A rekreációs lehetőségeket egyre inkább privatizálják (a sport kapcsán 1. Péter, László: Romania: Private Sport Sector at the Crossroads of Past Socialism and Present Capitalism. In: Laine, Antti - Vehmas, Hanna (eds.): The Private Sport Sector in Europe. A Cross-National Comparative Perspective. Cham: Springer, 2017. 287-308.), a szabadidős szolgáltatásokért fizetni kell, az emberek irányított, felügyelt körülmények között vehetik igénybe. A spontán interakciók lehetősége beszükül (pl. foci a grundon), ami nem kedvez az etnikumközi találkozásoknak sem, hiszen minél inkább szervezést igényel, annál valószínűbb, hogy a már létező, etnikailag integrált intézmények hálózatán keresztül fog megvalósulni.

${ }^{65}$ Van Parijs, Philippe: Linguistic Justice for Europe and for the World. Oxford University Press. 2011.; Csata, 2016.

${ }^{66}$ Csata Zsombor - Marácz László K.: Prospects on Hungarian as a Regional Official Language and Szeklerland's Territorial Autonomy in Romania. International Journal on Minority and Group Rights, 2016. 23(4). 530-559.
}

REGIO 27. évf. (2019) 1. szám 37-80. 
egyszerübbé vált, csökkentek a külföldi munkavállalás tranzakciós költségei, emellett olcsóbb lett és lerövidült az utazás is. Ehhez képest a román nyelvtanulás és ezzel összefüggésben a román etnikai határok átlépésének költségei nem változtak, vagy egyenesen növekedtek. Egyre több - különösen a magyar tömbvidékeken élö erdélyi magyar fiatal számára egy ésszerü döntés lehet tehát az, hogy inkább az angolt tanulja meg, és külföldön vállal munkát, mert annak a tanulási költségei alacsonyabbak (magasabb a médiakitettség, hatékonyabbak a tanulási módszerek), pozitívabbak a lélektani diszpozíciók $^{67}$ (barátságosabb az iskolai számonkérés és a kikényszerítés módja), ráadásul - ha nagyon szükséges - a románokkal is meg tudja értetni magát. Bár teljes intézményesülése egyelőre nagyon távolinak tünik, és valószínűleg soha nem valósul meg, a folyamatok spontán evolúciója mentén az angol, mint lingua franca további erősödésére számíthatunk. Az ebben rejlő lehetőségeket és kihívásokat a különböző interetnikus társadalmi projektek tervezésében érdemes komolyabban fontolóra venni ${ }^{68}$.

A dolgok jelenlegi állása mellett a nyelvgazdasági tényezők tehát a diverzitás csökkenésének és a párhuzamos társadalmak további erősödésének kedveznek a román-magyar viszonyban. Az etnikai alapú polarizációt tovább növelheti annak a megtapasztalása, hogy a románokkal kötött bridging típusú kapcsolatok általában nem váltják be a hozzájuk füzött reményeket. Elemzésünkből meglepő módon az derült ki, hogy az erdélyi magyarok nagy többsége számára ezek nem járnak relatív munkaerőpiaci vagy gazdasági elönyökkel. Ez az eredmény azonban még további ellenörzésre szorul.

${ }^{67}$ A gazdasági vonatkozások mellett a pszichológiai tényezők jelentőségét is méltánytalanul elhanyagolta a szakirodalom, holott óriási a jelentősége annak, hogy az idegen nyelvtanulás és -használat során az alanyok milyen formában és milyen visszajelzéseket kapnak a kompetens használóktól. A román nyelvtanulás általában formalizáltabb és szigorúbb, néha ésszerütlenül magas a mérce, gyakoribbak a negatív szankciók. Az angol számonkérése fesztelenebb és lazább, iskolában és az iskolán kívül egyaránt. Ez a különbség már önmagában elég ahhoz, hogy a gyerekek eltérő diszpozícióit magyarázza az angol, illetve a román tanulásával kapcsolatban.

${ }^{68} \mathrm{Az}$ angol, mint lingua franca gazdasági előnyeiről 1. Liu, Amy H.: Standardizing Diversity: the Political Economy of Language Regimes. University of Pennsylvania Press, 2015.

REGIO 27. évf. (2019) 1. szám 37-80. 
A munkaerőpiacon kívül pedig általában akkor járhat egy román kapcsolat relatív rekreációs előnnyel, ha nincs hasonló magyar alternatíva. Minél kevésbé ismeri valaki a román nyelvet, annál nagyobb a diszkomfort és az erőfeszítés mértéke egy románnal való társalgásban. Ha pedig már tökéletesen uralja a nyelvet, és észrevétlenül boldogul, még mindig ott van a „nyelvi főhajtás” hegemón müködö intézménye, ami arra emlékeztetheti, hogy anyanyelve másodrangú, szükségtelen, és hogy a „hasonló megbecsülés" elve nem érvényesül ${ }^{69}$. Távolról sem gondoljuk, hogy minden magyart minden románnal való érintkezésben ez az érzékenység jellemezne. Számunkra csupán az egyik változó egy olyan a modellben, ami az etnikai homofíliát a nyelvi aszimmetriával magyarázza.

Az eddigiek összefoglalásaképpen elmondhatjuk, hogy a román gazdaság regulációs környezetének anomáliái (szünni nem akaró korrupció, járadékvadászat, részrehajlás stb.), az intézményekkel és általában az emberekkel kapcsolatos bizalmatlanság, a kétnyelvüség aszimmetriája, a románokkal kialakított kapcsolatok elmaradó gazdasági hozadéka és a magyar népesség földrajzi koncentrációja olyan egymással összefüggő tényezők, melyek együttesen hozzájárulhatnak a bonding típusú kapcsolatok további felértékelödéséhez, az etnikai alapú fragmentáció növekedéséhez, az etnikailag integrált intézményrendszer további konszolidálódásához. A gazdasági életben nem beszélhetünk még az oktatáshoz, az egyházhoz vagy a kultúrához mérhető etnikai párhuzamosságokról, de számos jelét látjuk annak, hogy etnicitás szerepe az egyéni döntésekben és intézményi szinten egyaránt erősödőben van.

Individuális szinten láthattuk, hogy a bonding típusú kapcsolatok jobban hasznosulnak a gazdaságban, de nagyon erős a fogyasztói etnocentrizmus is, az erdélyi magyarok közel fele, ha tehetné, inkább egy magyartól vásárolna. Az idézett vizsgálatokból kiderült, hogy az etnocentrikus piaci preferenciák azokra jellemzőek inkább, akik magyar tömbvidéken, ,etnikai burokban” élnek, és bizalmatlanok a románokkal szemben, nem függ viszont a vásárlók nemétől, korától, iskolai végzettségétől és vagyoni helyzetétől sem. Az Erdély különböző szegleteiből érkező, Kolozsváron tanuló magyar diákokra

${ }^{69}$ Van Parijs, 2011. 142.

REGIO 27. évf. (2019) 1. szám 37-80. 
vonatkozó vizsgálat azt is kimutatta, hogy a román nyelvi kompetenciák hiánya is szignifikánsan befolyásolja azt, hogy a fogyasztók etnikai alapon döntenek. Minden jel arra mutat tehát, hogy a magyar népesség földrajzi koncentrációjával és a román nyelvtudás romlásával párhuzamosan az etnocentrikus gazdasági diszpozíciók várhatóan tovább fognak erősödni.

Intézményi szinten az etnikai vállalkozások helyzetét érdemes figyelemmel követni. Az etnikailag szervezett gazdaság intézményesülése valójában az utóbbi években, főként a közigazgatás decentralizációját és az ország uniós csatlakozását követően erösödhetett fel, addig a müködése garantálásának a feltételei meglehetősen hézagosak voltak. A decentralizáció lehetőséget teremtett arra, hogy az önkormányzatok és az általuk létrehozott gazdaság- vagy vállalkozásfejlesztő civil szervezetek önálló etnikai projekteket kezdeményezzenek és hozzanak létre a piacon. Ennek egyik objektiválódása a Székelyföldön a „székely termék” védjegyek megjelenése, amelyek több - most már egymással konkurens termelői és disztribúciós hálózatba szervezve próbálják értékesíteni a helyi, székely vállalkozók termékeit ${ }^{70}$. Bár a müködtetésükkel kapcsolatban folyamatos problémák merülnek fel, ez a szegmens folyamatosan növekszik és további bővülése várható.

Az említett második feltétel, az uniós kereskedelmi jog bevezetése zavartalan lehetőséget teremt a magyar nyelv használatára a fogyasztói piacon. Ennek köszönhető, hogy az utóbbi időben nemcsak az önkormányzati patronátussal müködő egységek, hanem ezektől független magánvállalkozók is kezdik felismerni a magyar nyelvü marketingben és ezáltal az etnikai piacban rejlő lehetöségeket. Egyre több olyan regionális termék jelenik meg, amely kommodifikálja azokat a pozitív jelentéseket, amelyeket a közösen megélt és formált történelmi tapasztalatra hivatkozva a „székely” jelző köré épít.

Ezeknek a kezdeményezéseknek a gazdasági hatása egyelöre nagyon korlátozott: távolról sem mondhatjuk, hogy jelentősen hozzájárulnának a magyar lakosság gazdasági helyzetének érdemi javításához. Az erdélyi magyar társadalom szempontjából a jelentőségük egyelőre sokkal inkább csak szimbolikus, de hasznos funkciójuk van például abban, hogy a piaci dereguláció farvizén

${ }^{70}$ Gál, 2011.

REGIO 27. évf. (2019) 1. szám 37-80. 
bevigyék a kétnyelvűséget a gazdaságba, és ezen keresztül kitegyék a szélesebb nyilvánosság elé.

A jelenlegi regulációs feltételek fennmaradása mellett valószínü viszont, hogy ennek a típusú „etnikai piacnak” a további bővülése várható, és jó esély van arra is, hogy manifeszt funkcióját - a magyar vállalkozások gyarapodását, a magyar üzleti élet fejlesztését - is nagyobb mértékben lesz képes ellátni. Ennek a várakozásnak az a „fogyasztói etnocentrizmus" ad alapot, aminek fontosabb jellemzőit ebben a tanulmányban bemutattuk.

A terjedelmi korlátok miatt, és mert az egyéni hatása nem volt szignifikáns, a bridging tőke jelentőségével ebben a dolgozatban keveset foglalkoztunk. Teljességgel jogosaknak érezzük azonban azokat az aggályokat, amelyeket a bridging tőke kollektív szükösségével kapcsolatban a szakirodalom megfogalmaz ${ }^{71}$. Társadalmi értelemben a bridging tőke segít ellensúlyozni azokat az anomáliákat, amelyet a bonding tőke felerősödése, túlburjánzása okozhat, mint amilyen a mássággal szembeni averzió, a csoporton kívüliekkel szembeni kirekesztés és intolerancia, ami komoly társadalmi feszültségek és konfliktusok forrása lehet. A bridging tőke krónikus hiányának azonban - ahogyan a bevetőben is jeleztük nemcsak a társadalmi, hanem a gazdasági következményei is fájdalmasak lehetnek. Ezek közül a legfontosabb az információs potenciál csökkenése, tehát hogy a magyar vállalkozók megfelelő kapcsolatok híján lemaradhatnak olyan értékes piaci információkról, korszerü üzleti megoldásokról, amelyek fontosak lennének a gyarapodáshoz, és ezzel komparatív hátrányba kerülnek a versenytársakkal szemben. Ezt a hátrányt valószínüleg az erősödő magyarországi kormányzati és üzleti befolyás csak részlegesen tudja ellensúlyozni - az erdélyi magyar termékek például nehezen találnak magyarországi piacokat. Kollektív szinten a gazdaság országos szintü, vertikális integrálatlansága a magyar többségü régiók további lemaradásához vezethet. Nagyon valószínü, hogy a bridging kapcsolatok leépülése együtt jár a román nyelvtudás romlásával is,

${ }^{71}$ Putnam, Robert D.: Bowling alone: The collapse and revival of American community. New York: Simon and Schuster, 2001.; Orbán - Szántó, 2005.

REGIO 27. évf. (2019) 1. szám 37-80. 
aminek a kézzel fogható veszteségei egyes iparágakban - például a székelyföldi turizmusban - korábban is mérhetőek voltak. ${ }^{72}$

\section{Felhasznált irodalom}

Aldrich, Howard E. - Roger, Waldinger: Ethnicity and entrepreneurship. Annual Review of Sociology, 1990. Volume 16, issue 1. 111-135.

Alesina, Alberto - Eliana La Ferrara: Ethnic diversity and economic performance. Journal of Economic Literature, 2005. Volume 43, issue 3. 762-800.

Benő Attila: Hogyan tanulják a magyar gyerekek a román nyelvet az erdélyi iskolákban? Problémák és lehetőségek. Székelyföld, 2012. május.

Brubaker, Robert - Feischmidt Margit - Fox, Jon - Grancea, Livia: Nationalist Politics and Everyday Ethnicity in a Transylvanian Town. Princeton University Press, 2018.

Burt, Ronald S.: Structural Holes: The Social Structure of Competition. Cambridge: Harvard University Press, 1995.

Chiswick, Barry R. - Miller, Paul W.: The economics of language: International analyses. Routledge, 2007.

Csata Zsombor - Dániel Botond - Pop, Carmen: Pályakezdő fiatalok a munkaeröpiacon. Erdélyi Társadalom, 2006. Volume 4, issue 1. $7-27$.

72 A román nyelvtudás hiányából fakadó nehézségekről bővebben 1 . Csata Zsombor és Pásztor Gyöngyi jelentését a Kovászna megyei vidéki turizmus helyzetéről: Csata Zsombor - Pásztor Gyöngyi: Összehasonlító régiótanulmány a vidéki turizmusra és a foglalkoztatottságra vonatkozóan Bihar és Kovászna megyében. Bukarest.: OTP Consulting, 2015. Ebben a tekintetben beszédes az is, hogy a Székelyföldre érkező turisták kevesebb mint fele román, többségük az állam által szubvencionált, gyógykezelési célú „nyudíjas-jegyekkel” érkezik, 1. Kiss Tamás - Barna Gergő - Deák Attila: Székelyföld turisztikai régió. Kérdőives, fókuszcsoportos és statisztikai vizsgálat a székelyföldi turizmusról. Kolozsvár: Nemzeti Kisebbségkutató Intézet-Kvantum Research, 2013.

REGIO 27. évf. (2019) 1. szám 37-80. 
Csata Zsombor - Deák Attila. Gazdasági etnocentrizmus, etnikai fogyasztás az erdélyi magyarok körében. Közgazdász Fórum, 2010. Volume 13, issue. 95. 31-48.

Csata Zsombor: Confiance ou scepticisme: l'evaluation des institutions civiles et politiques en Roumanie. In: Sossa, Dorothé (ed.): Nouvelles democraties et socialisation politique. Etude comparee des cas du Benin, du Bukina Faso et de la Roumanie. Paris: L'Harmattan, 2011. 181-204.

Csata Zsombor: The Social Determinants of Entrepreneurial Activity in Rural Transylvania. Studia Sociologia, 2012/1. 101-124.

Csata Zsombor: A fogyasztói magatartás etnikai vonatkozásai a kolozsvári magyar egyetemi hallgatók körében - Kutatásjelentés. Kolozsvár: BBTE Magyar Szociológia és Szociális Munkásképző Kar, 2014.

Csata Zsombor: Ethnicity and Economy. A Research Agenda for Transylvania. Erdélyi Társadalom (Transylvanian Society). 2015a. 3. 31-46.

Csata Zsombor - Pásztor Gyöngyi: Összehasonlitó régiótanulmány a vidéki turizmusra és a foglalkoztatottságra vonatkozóan Bihar és Kovászna megyében. Bukarest.: OTP Consulting, $2015 b$.

Csata Zsombor: Reflections on the economic aspects of multilingualism in Transylvania. Belvedere Meridionale, 2016a. 28(2). 51-65.

Csata Zsombor - Marácz László K.: Prospects on Hungarian as a Regional Official Language and Szeklerland's Territorial Autonomy in Romania. International Journal on Minority and Group Rights, 2016b. 23(4). 530-559.

Csata Zsombor: Munkaerőpiaci egyenlőtlenségek Romániában, etnikai metszetben. Erdélyi Tásadalom, 2017. 15(1). 81-104.

Dániel Botond: Erdélyi magyar fiatalok jövőterveinek, munkaerőpiaci helyzetének, etnikai fogyasztásának vizsgálata. In: Szabó Andrea - Bauer Béla - Pillók Péter (szerk.): Mozaik 2011 Magyar fiatalok a Kárpát-medencében. Kutatási jelentés.

REGIO 27. évf. (2019) 1. szám 37-80. 
Szeged-Budapest: Belvedere Meridionale - Nemzeti Család- és Szociálpolitikai Intézet, 2013. 169-198.

Eriksen, Thomas Hylland: Economies of ethnicity. In: Carrier, James G. (ed.) A Handbook of Economic Anthropology. Cheltenham, UK - Northampton, MA: Edward Elgar, 2005. 353-369.

Gáll Zoltán: Fából vaskarika? Avagy: lehet-e a székely termék világmárka? Pro Minoritate, 2011/2. 54-71.

Geambașu Réka: „A kódolás élvezete”. A kolozsvári programozók. Kézirat, 2017.

Granovetter, Mark: The strength of weak ties. American Journal of Sociology, 1973. 78(6). 1360-1380.

Granovetter, Mark: Economic action and social structure: The problem of embeddedness. American Journal of Sociology, 1985. 91(3). 481-510.

Granovetter, Mark: The Economic Sociology of Firms and Entrepreneurs. In: Portes, Alejandro (ed.): Economic Sociology of Immigration. Essays on Network, Ethnicity and Entrepreneurship. New York: Russell Sage Foundation, 1995. $128-162$.

Grin, Francois. On the costs of cultural diversity. In: Van Parijs, Philippe (ed.): Cultural Diversity vs. Ethnic Solidarity. Bruxelles: DeBoeck - Larcier, 2004. 189-202.

Grin, Francois: Langue et différentiels de statut socio-économique en Suisse. Berne: Office Fédéral de la Statistique, 1997.

Harford, Tim. Messy: How to be creative and resilient in a tidyminded world. Hachette UK: Little Brown Book Group, 2016.

Horváth István: Az erdélyi magyarok kétnyelvüsége: nyelvmentés és integráció között. Erdélyi Társadalom, 2003. 1(1). 7-23.

Horváth István: Elemzések a romániai magyarok kétnyelvüségéröl. Mühelytanulmányok a romániai kisebbségekröl 8. Kolozsvár: Nemzeti Kisebbségkutató Intézet, 2008.

REGIO 27. évf. (2019) 1. szám 37-80. 
Kiss Tamás: Vállalkozástörténetek Erdélyben. In: Kovács Éva (szerk.): A gazdasági átmenet etnikai tájképei. Budapest: Teleki László Alapítvány, 2004. 23-128.

Kiss Tamás: Etnikai rétegződési rendszer Erdélyben és Romániában. A magyarok társadalmi pozíciói 1. REGIO, 22 (2). 2014. 187245.

Kiss Tamás: Increasing Marginality, Ethnic Parallelism and Asymmetric Accommodation. Social and Political Processes Concerning the Hungarian Community of Transylvania. Minority Studies, 2015/1. 33-69.

Kiss Tamás: Az erdélyi magyarok médiafogyasztása. Erdélyi Társadalomtudományi Lexikon. Kolozsvár: Jakabffy Elemér Alapítvány - Transindex. 2015.

Kiss Tamás - Barna Gergö - Deák Attila: Székelyföld turisztikai régió. Kérdöives, fókuszcsoportos és statisztikai vizsgálat a székelyföldi turizmusról. Kolozsvár: Nemzeti Kisebbségkutató Intézet-Kvantum Research, 2013.

Kiss Tamás - Székely István Gergő - Toró Tibor - Bárdi Nándor Horváth István (eds.): Unequal Accommodation of Minority Rights: Hungarians in Transylvania. Cham: Springer, 2018.

Lancee, Bram: Immigrant performance in the labour market: Bonding and bridging social capital. Amsterdam: Amsterdam University Press, 2012.

Landa, Janet T.: Trust, ethnicity, and identity: beyond the new institutional economics of ethnic trading networks, contract law, and gift-exchange. University of Michigan Press, 1994.

Lewis, Tania - Potter, Emily: Ethical consumption: A critical introduction. Routledge, 2013.

Light, Ivan - Gold, Steven: Ethnic Economies. San Diego, CA: Academic Press. 2000.

Liu, Amy H.: Standardizing diversity: the political economy of language regimes. University of Pennsylvania Press, 2015.

REGIO 27. évf. (2019) 1. szám 37-80. 
Narayan, Deepa: "Bonds and bridges: social capital and poverty." Social capital and economic development: well-being in developing countries. Northampton, MA: Edward Elgar, 2002. 58-81.

Orbán Annamária - Szántó Zoltán: Társadalmi tőke. Erdélyi Társadalom, 2005. 3(2). 55-70.

Ottaviano, Gianmarco IP. - Peri, Giovanni: The economic value of cultural diversity: evidence from US cities. Journal of Economic Geography, 2006. 6(1). 9-44.

Page, Scott E.: The Difference: How the Power of Diversity Creates Better Groups, Firms, Schools, and Societies. Princeton University Press, 2008.

Papp Z. Attila - Márton János: Párhuzamos világok? Az erdélyi magyar gazdasági és kulturális elit szocio-demográfiai jellemzői. In: Kovách Imre (szerk.): Elitek a válság korában. Magyarországi elitek, kisebbségi magyar elitek. Budapest: Magyar Tudományos Akadémia Politikatudományi Intézet, Magyar Tudományos Akadémia Etnikai-Nemzeti Kisebbségkutató Intézet, Argumentum Kiadó, 2011. 463-522.

Papp Z. Attila: Az 1989 utáni romániai, illetve romániai magyar elitek tipológiái és értelmezései. In: Kovách Imre (szerk.): Elitek a válság korában. Magyarországi elitek, kisebbségi magyar elitek. Budapest: Magyar Tudományos Akadémia Politikatudományi Intézet, Magyar Tudományos Akadémia Etnikai-Nemzeti Kisebbségkutató Intézet, Argumentum Kiadó, 2011. 463-522.

Péter, László: Romania: Private Sport Sector at the Crossroads of Past Socialism and Present Capitalism. In: Laine, Antti - Vehmas, Hanna (eds.): The Private Sport Sector in Europe. A CrossNational Comparative Perspective. Cham: Springer, 2017. 287308.

Portes, Alejandro: Social capital: Its origins and applications in modern sociology. Annual Review of Sociology, 1998. 24(1). 124.

REGIO 27. évf. (2019) 1. szám 37-80. 
Portes, Alejandro - Sensenbrenner, Julia: Embeddedness and immigration: Notes on the social determinants of economic action. American Journal of Sociology, 1993. 98(6). 1320-1350.

Putnam, Robert D.: Bowling alone: The collapse and revival of American community. New York: Simon and Schuster, 2001.

Putnam, Robert D.: E pluribus unum: Diversity and community in the twenty-first century the 2006 Johan Skytte Prize Lecture. Scandinavian Political Studies, 2007. 30(2). 137-174.

Shimp, Terence A.: Consumer ethnocentrism: The concept and a preliminary empirical test. Advances in Consumer Research Volume 11, 1984.

Szabó Árpád Töhötöm: Etnikai különbségtétel a paraszti gazdaságban. In: Feischmidt Margit (szerk.) Etnicitás: Különbségteremtö társadalom. Budapest: Gondolat - MTA Etnikai-Nemzeti Kisebbségkutató Intézet, 2010.

Szabó Árpád Töhötöm: Dairy Cooperative in the Making: History, Ethnicity and Local Culture in an Economic Enterprise. Erdélyi Tásadalom (Transylvanian Society), 2015/3. 31-46.

Szilágyi N. Sándor: De ce nu-şi pot însuşi copiii maghiari limba română în şcoală? Altera, 1998/7.

Tódor Mária Erika: A kódváltás és az aszimmetrikus kétnyelvüség nyelvpedagógiai összefüggései. Magyar Pedagógia, 2005/105. 41-58.

Vaillancourt, Francois: Language and socioeconomic status in Quebec: measurement, findings, determinants, and policy costs. International Journal of the Sociology of Language, 1996. 121(1), 69-92.

Van Parijs, Philippe: Linguistic Justice for Europe and for the World. Oxford University Press. 2011.

Wickström, Bengt-Arne - Landa, Janet Tai: Interethnic relations, informal trading networks, and social integration: imitation, habits, and social evolution. Journal of Bioeconomics, 2018. 20(3). 263-286.

REGIO 27. évf. (2019) 1. szám 37-80. 